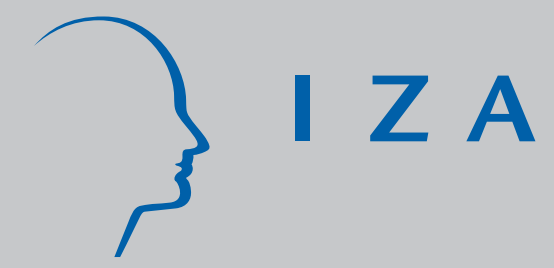

IZA DP No. 1509

Child Poverty and Family Transfers in Southern Europe

Manos Matsaganis

Horacio Levy

Magda Mercader-Prats

Stefano Toso

March 2005
Cathal O'Donoghue

Manuela Coromaldi

Carlos Farinha Rodrigues

Panos Tsakloglou 


\title{
Child Poverty and Family Transfers in Southern Europe
}

\section{Manos Matsaganis}

University of Crete

Horacio Levy

Autonomous University of Barcelona

Magda Mercader-Prats

Autonomous University of Barcelona

Stefano Toso

University of Bologna
Cathal O'Donoghue

National University of Ireland at Galway

and IZA Bonn

Manuela Coromaldi

University of Rome "Tor Vergata"

\section{Carlos Farinha Rodrigues}

Technical University of Lisbon

\section{Panos Tsakloglou}

Athens University of Economics \&

Business and IZA Bonn

Discussion Paper No. 1509

March 2005

\author{
IZA \\ P.O. Box 7240 \\ 53072 Bonn \\ Germany \\ Phone: +49-228-3894-0 \\ Fax: +49-228-3894-180 \\ Email: iza@iza.org
}

\begin{abstract}
Any opinions expressed here are those of the author(s) and not those of the institute. Research disseminated by IZA may include views on policy, but the institute itself takes no institutional policy positions.

The Institute for the Study of Labor (IZA) in Bonn is a local and virtual international research center and a place of communication between science, politics and business. IZA is an independent nonprofit company supported by Deutsche Post World Net. The center is associated with the University of Bonn and offers a stimulating research environment through its research networks, research support, and visitors and doctoral programs. IZA engages in (i) original and internationally competitive research in all fields of labor economics, (ii) development of policy concepts, and (iii) dissemination of research results and concepts to the interested public.
\end{abstract}

IZA Discussion Papers often represent preliminary work and are circulated to encourage discussion. Citation of such a paper should account for its provisional character. A revised version may be available directly from the author. 


\section{ABSTRACT \\ Child Poverty and Family Transfers in Southern Europe*}

The drive to reduce child poverty is of particular interest in southern Europe, where the subsidiary role of the State in matters of family policy has implied that programmes of public assistance to poor families with children are often meagre or not available at all. The paper examines the effect of family transfers (used broadly to include contributory family allowances, non-contributory child benefits and tax credits or allowances) on child poverty in Greece, Italy, Spain and Portugal. Using the European microsimulation model EUROMOD, the paper first assesses the distributional impact of existing family transfers and then explores the scope for policy reforms. By way of illustration, the effects of universal child benefit schemes similar to those in Britain, Denmark and Sweden are simulated. The paper concludes with a discussion of key findings and policy implications.

JEL Classification: $\quad$ C81, D31, I38

Keywords: child poverty, social transfers, fiscal benefits, south Europe, microsimulation

Corresponding author:

Panos Tsakloglou

Department of International and European Economic Studies

Athens University of Economics \& Business

76 Patission Str.

Athens 10434

Greece

Email: panos@aueb.gr

\footnotetext{
${ }^{*}$ This paper was written as part of the MICRESA (Micro Analysis of the European Social Agenda) project, financed by the European Commission under the Improving Human Potential programme (SERD-2001-00099). Previous versions of this paper were presented at workshops and seminars held in Vienna, Paris, Milan, the final conference of the COST-A15 programme (Nantes), the 2004 conference of the International Association of Research on Income \& Wealth (Cork) and at the $10^{\text {th }}$ Congress of the Basic Income European Network (Barcelona). The authors are grateful to the discussants and other participants for their comments and suggestions. The national versions of the EUROMOD models would not have existed without the hard work of Holly Sutherland and her team at the Microsimulation Unit, University of Cambridge. Obviously, all errors relating to the use of the national models and the interpretation of the results are the responsibility of the authors. EUROMOD is continually being improved and updated and the results presented here should be viewed as work in progress. The version of the model used was $17 \mathrm{~A}$.
} 


\section{Introduction}

Child poverty has risen to prominence as a distinct issue of social policy over the last few years. There is a variety of reasons for this development. On the one hand, concern with child poverty seems to appeal to all. As a matter of fact, the distinction between the "deserving" and the "undeserving" poor (as old as social policy itself, but arguably never quite forgotten) is not suited to a view on child poverty. Therefore, policies against child poverty enjoy much wider support than general anti-poverty policy can ever hope to muster. On the other hand, there is sufficient evidence on the social costs of child poverty and the benefits of early intervention. In the light of this, policy measures to combat child poverty can be justified on the grounds of the high future returns reasonably expected of such investment on human capital ${ }^{1}$.

In view of the above, the recent emphasis on child poverty on the part of policy makers looking to establish new areas of consensus on social policy can hardly be surprising. In the United States, the Clinton administrations greatly expanded the scope of Earned Income Tax Credit, which has now become the main instrument for the provision of income support to families. In Britain, the Labour government has committed itself to halving child poverty by the year 2010. A variety of policy instruments are to be employed, including substantial improvements to universal Child Benefit and of the child supplements to means-tested Income Support, as well as the extensive use of in-work benefits ${ }^{2}$.

Nearer home, from a south European perspective, the European Commission's contribution to the Lisbon summit in March 2000 included a proposal to halve child poverty by 2010. Although eventually this proposal was not endorsed by the European Council, the Social Inclusion Process confirmed the greater visibility of anti-poverty policy at the level of the EU. Moreover, the elaboration of biennial National Action Plans since May 2001 has been in many countries, including those examined here, the occasion for initiatives specifically targeted to children ${ }^{3}$.

The drive to reduce child poverty is of particular interest in the context of southern Europe. If anything, "familialism" has long been identified as a special ingredient of south European welfare states. At first glance, it might be thought that in such a context families and children are well looked after. Rather paradoxically perhaps, this is not the case. On the one hand, family activism in the domain of social policy has proved far from fully effective in terms of preventing child poverty. The mobilisation of family resources to bail out relatives at risk of poverty requires that such resources are adequate in the first place, even when the existence of families or their willingness to help is not an issue. On the other hand, the "subsidiary" role of the State in matters of family policy has often implied that formal programmes of public assistance to poor families with children are meagre or not available at all ${ }^{4}$.

The limited role of social assistance for low-income families with children in the countries of southern Europe is in sharp contrast to the extensive (and, from a political point of view, rather "unproblematic") reliance on tax benefits. Fiscal welfare, mostly taking the form of non-refundable income tax credits for dependent children, seems to be alive and

\footnotetext{
${ }^{1}$ For a detailed analysis see Esping-Andersen et al (2002) and Esping-Andersen \& Sarasa (2002).

${ }^{2}$ For an early assessment of the drive to reduce child poverty in Britain see Piachaud \& Sutherland (2003). Working Families Tax Credit and Child Care Tax Credit (introduced in 1998) were consolidated to the new Child Tax Credit in 2002. For a review see Brewer (2003). For an assessment of means-tested programmes in the US see the various contributions in Moffitt (2002).

${ }^{3}$ For a detailed analysis of the open method of co-ordination as applied to the social inclusion process see Ferrera et al (2002). For a full review of the National Action Plans see the joint inclusion reports issued by the European Commission in December 2001 and in December 2003 respectively. For a good child audit of the 2001 National Action Plans see Ruxton \& Bennett (2002).

${ }^{4}$ For a classic analysis of south European welfare see Ferrera (1996). See also the collection of articles edited by Rhodes (1996). For a recent review of anti-poverty policy in southern Europe see Matsaganis et al (2003).
} 
well and causing the same regressive outcomes predicted by Titmuss many years ago ${ }^{5}$. The combination of limited social assistance and the extensive recourse to fiscal benefits results in uneven coverage, with gaps where protection is needed most. The provision of categorical family allowances on a contributory basis compounds such fragmentation.

This paper aims to assess the impact of family transfers on child poverty in Greece, Italy, Spain and Portugal. The term "family transfers" is used broadly to include noncontributory child benefits, contributory family allowances and tax credits or allowances for dependent children ${ }^{6}$. The analysis relies on EUROMOD, a cross-country comparative benefit-tax model for all 15 members of the EU. Microsimulation models like EUROMOD allow users not only to evaluate the impact of existing tax and benefit measures but also to simulate the effects of alternative policy reforms. Both features are brought to use here.

The structure of the paper is as follows. The next section briefly describes the data and methodology used here. Section three reviews the incidence of child poverty by family type in southern Europe. Section four offers an account of family transfer programmes in the four countries. Section five assesses the distributional impact of existing family transfers. Section six simulates the effects of reforms to family transfers. The paper concludes with a discussion of key findings and their policy implications. Finally, policy updates and official statistics on child poverty are provided in the Appendix.

\section{Data and methodology}

This paper relies on the output of EUROMOD, a cross-country comparative benefit-tax model. The model simulates a variety of taxes and benefits in each of the 15 countries of the EU. The policy instruments simulated here include income taxes, social insurance contributions, social assistance benefits, unemployed benefits, housing benefits, family benefits and, where possible, social insurance benefits.

EUROMOD simulates policy rules for particular countries as they existed in 1998, applied on the original micro-data sets drawn from family income surveys. The data used in this paper are derived from the Bank of I taly Household Income Survey (1995) and from the European Community Household Panel for Greece (1995), Portugal (1996) and Spain (1996). Income data have been updated to the year 1998, using appropriate adjustment factors by country and by income source.

The advantages of a microsimulation model such as EUROMOD are quite obvious. Benefit information is normally collected as part of surveys such as the above. Nevertheless, the benefits of interest (here family transfers) are often difficult to identify because of aggregation. Moreover, income taxes are almost impossible to read off the original data. Finally, the data year is inevitably not the same as the policy year under examination. As a result, it is impossible to estimate the effect of policies introduced or modified after the data were collected - except through microsimulation. In view of all this, the model constitutes a powerful tool for research on reforms to social security and the fiscal system in a comparative perspective.

Equally obvious are the disadvantages. EUROMOD is a static model, based upon purely arithmetical calculations. As such, it cannot account for behavioural responses, such as those related to labour supply decisions, when simulating the effects of policy changes.

\footnotetext{
${ }^{5}$ See the collected essays of Richard Titmuss edited by Alcock et al (2001). The issue is dealt with in particular in Part IV: Fiscal and occupational welfare and the myth of economic man.

${ }^{6}$ In a recent study, Levy (2003) adopted a still broader definition of family transfers than the one used here, one that included all child-related instruments anywhere in the social benefit system. Indeed, the practice of adding special allowances for dependent children to policy instruments as diverse as old age pensions, unemployment benefits, housing benefits and so on is quite diffuse in southern Europe. In view of that, this approach is promising (and a good demonstration of the analytical power of tax-benefit models). Nevertheless, a more straightforward approach is followed in this paper, restricted to policy instruments specifically targeted to children.
} 
Moreover, due to data limitations, it should be noticed that in-kind benefits and publicly provided services are not examined here. This is an important omission: non-cash benefits have an important effect on family and child welfare and play a major role in the policy debate in many countries. This is an issue we will return to later on in the paper.

A further set of methodological problems is potentially more amenable to treatment. The application of policy rules to a given population implies that these rules are fully adhered to. Of course, this is not true in the real world. On the one hand, not all individuals claim the benefits they are entitled to. It is known that non-take up is caused by fear of stigma, incomplete information about entitlements, administrative errors and other reasons. It is also known that the extent of non-take up can be considerable with respect to means-tested benefits, though much less so with respect to universal benefits. However, non-take up of social benefits in the countries of southern Europe is neglected as a policy issue and relatively overlooked as a research issue ${ }^{7}$. Similarly, there may be "leakage" of means-tested benefits to non-entitled households or individuals. For the purposes of this paper, the impact of family transfers is assessed as if all benefits were perfectly targeted, in the sense of being fully taken up by all legitimate claimants and received by no illegitimate ones.

On the other hand, not all individuals pay the taxes they are liable to. Tax evasion is known to constitute a serious issue, all the more so in the countries of southern Europe. Again, no adjustment is made to the data, as if the incomes reported in the surveys on which the model relies were the same as the incomes declared to the authorities for the purposes of assessing both liability to income tax as well as eligibility to income-related benefits. The implications of the twin assumptions of perfect tax compliance and perfect targeting are discussed in the conclusions.

The objective of this paper is to assess the effect of family transfers on child poverty and to examine the role of reforms that are variations on the theme of universal child benefits. In line with the recommendation of UNICEF, children are defined as individuals below 18 years of age. Differences in household size and composition are dealt with by applying the modified OECD equivalence scale, as used by EUROSTAT. Household income is assumed to be equally shared among household members. The poverty line is set at 60 per cent of the median per capita equivalent disposable income in the "baseline scenario" and is held constant in simulated reforms.

\section{Household composition and child poverty}

The importance of the family has long been identified as an outstanding feature of southern Europe. In this part of the world, families function as an informal but effective social safety net, across a whole range of policy areas (including child care, care for the elderly, unemployment assistance, housing and social assistance).

Resource pooling between family members needs not operate within households, but it usually does. As a matter of fact, the common assumption of equal sharing of resources on which most current research on poverty - including the research presented here rests may not fully capture what actually goes on inside many south European families. There is evidence that low income families go to very considerable lengths to ensure that their children appear less "different" to their peers than might have been expected on the basis of family income alone (for example, by spending a larger share of the family budget on expensive clothing and footwear) ${ }^{8}$.

\footnotetext{
${ }^{7}$ For a recent survey of non-take up of social security benefits in Europe see Hernanz et al. (2004).

${ }^{8}$ For an excellent analysis of family and consumption in contremporary Italy see Ginsborg (2001: chapter 3). Incidentally, in the absense of a theory and more robust evidence of how family budgets are actually allocated between family members, replacing the rule of equal sharing of resources by any other would risk introducing a greater dose of arbitrariness. Nevertheless, if poor families really spend a disproportionate amount of their scarce resources on their children, the position of southern Europe in the child poverty league would have to be revised upwards.
} 
There is evidence that such resource pooling intensified as youth joblessness remained high or increased. It is remarkable that the proportion of young persons aged 25-29 still living with their parents rose between 1987 and 1996 from 39 to 50 per cent in Greece, from 39 to 59 per cent in Italy, from 49 to 62 per cent in Spain and from 39 to 52 per cent in Portugal. The equivalent figure in the EU as a whole was a mere 32 per cent ${ }^{9}$.

Moreover, as much of current research has emphasised, social change has undermined the assumption of a working husband supporting a housewife and their children, or the "male breadwinner model" on which welfare state building in the post-war period implicitly relied. The decline of the traditional family and the rise of atypical family forms have exposed certain population groups to a higher poverty risk, single mothers and their children being the most widely discussed case $^{10}$.

In the light of the above, it follows that the point of departure for any discussion of child poverty in southern Europe must be an analysis of household composition. This is shown in Table 1.

\section{[TABLE 1]}

As Table 1 shows, most children in southern Europe still live in "standard" families of father, mother and their one or two children, ranging from 47 per cent in Portugal and 55 per cent in Spain and Italy through to 60 per cent in Greece. The incidence of families with grown-up children (i.e. aged over 18) is comparatively large. The same is true for the proportion of children in large or extended families ("other household types"). On the contrary, lone parent families account for a relatively low share of the child population, especially if one focuses on those with children below 18 (single parent families with older children are likely to include more widows than never-married mothers).

In the light of the above, when analysing child poverty in southern Europe it is useful to distinguish between poverty rates and contribution to aggregate child poverty. The former is simply the proportion of children in a certain household type that are below the poverty line. The latter is a function of the population share of each household type, calculated as the number of poor children in a certain household type as a proportion of all poor children ${ }^{11}$.

The implications of this distinction are more clearly brought out in Table 2 . In terms of poverty rates, child poverty rates are highest in large and lone parent families. In this sense, there is nothing remarkable about child poverty in southern Europe compared to the rest of Europe. In terms of contribution to aggregate child poverty, a very different picture emerges. In the case of lone parent families this is clearly limited: from about 8 per cent of all poor children in Italy to 15 per cent in Portugal. Large families account for a higher share of poor children, especially in the three Latin countries ${ }^{12}$. Yet, a very substantial proportion of children in poverty (ranging from 29 per cent in Portugal to 48 per cent in Greece) live in "standard" families of couples with one or two children.

\section{[TABLE 2]}

Turning to the age profile of poverty, Table 3 shows that the risk of poverty is higher for children than it is for the population as a whole in all countries except Greece. On the

\footnotetext{
${ }^{9}$ For a more detailed analysis of youth independence in southern Europe see Fernández Cordón (1997). The statistics cited are reported in Ferrera et al (2000).

${ }^{10}$ For a lucid analysis of social changes and their implications for social policy see Lewis (2001). For a south European perspective see Saraceno (1997).

${ }^{11}$ Note that any estimate of child poverty by household type is sensitive to the equivalence scale used. Other things being equal, the lower the household economies of scale implicit in the equivalence scale used with respect to children, the higher the headcount poverty rate and the contribution to aggregate child poverty of children living in larger households.

12 Other evidence suggests that the poverty rate for families with three or more children in Greece reported here is an underestimate (see Table A.3 in the Appendix). As explained in section 5.2, the prinicipal reason for this is that our analysis assumes perfect targeting of benefits. Since benefits to large families are particularly generous in Greece, their anti-poverty impact under conditions of full take up is shown to be strong. This point is discussed more fully later on.
} 
other hand, poverty rates for the elderly are lower than for children in Italy and in Spain, while the opposite is true for Greece and Portugal.

[TABLE 3]

Naturally, "headcount" rates tell only part of the story. For instance, a look at the income gap ratio, or the average income shortfall of poor families from the poverty line as seen in Table 4, reveals that the "depth" of child poverty is greatest in Greece and smallest in Portugal. Remember that the opposite is true with respect to the poverty rate ( 17 per cent in Greece vs. 23 per cent in Portugal). In other words, while proportionally fewer children find themselves below the poverty line in Greece compared to the other south European countries, those who do have lower relative incomes on average.

\section{[TABLE 4]}

The picture slightly changes again if a poverty indicator is adopted that attaches greater weight to larger income gaps, such as the index suggested by Foster, Greer \& Thorbecke (1984). The FGT index simultaneously takes into account the poverty rate, the income gap and the extent of inequality among the poor ${ }^{13}$. In the right-hand panel of Table 4, the index values are shown for a (the poverty aversion parameter) equal to 2 .

Contrasting headcount ratios with income gaps and the FGT index is a useful reminder of the fact that the effectiveness of policy (the main focus of this paper) cannot be simply read off official poverty statistics based exclusively on headcount ratios. The impact of family transfers on child poverty is discussed later on. Before that, the paper turns to the nature of family transfers in the south European countries. A brief account of the relevant arrangements in the domain of social security or the tax system for each of the four countries in turn is provided below.

\section{National policy profiles}

In all four countries of southern Europe income transfers to families include occupational family allowances, non-contributory benefits and tax relief for dependent children.

In Greece, substantial assistance to large families is provided through the " $3^{\text {rd }}$ child benefit" and the "large family benefit", funded out of general taxation. Since 2002, these are no longer income tested. Another non-contributory benefit but of lower value is "unprotected child benefit", aimed to low-income single parent families or households caring for orphans born to relatives (i.e. foster families are not eligible). Civil servants receive family allowances as salary supplements, while similar but lower allowances are paid to private sector employees conditional on adequate contributory record. Finally, child tax credits reduce the tax bill of eligible tax payers at a flat rate and on a nonrefundable basis. In 2002, a new refundable tax credit was introduced, targeted at lowincome families with children at school aged 6-16.

In Italy, the main transfer to households with children is "family allowance", a contributory benefit reserved to dependent workers (active or retired). The amount of benefit increases with household size and is inversely related to household income (since 1983). Two non-contributory schemes were introduced in 1999: a "benefit to large families" for households with three or more children and a "maternity allowance" for mothers not covered by social insurance. Both schemes are tested with the Indicator of Economic Situation (ISE), an instrument combining information on household income and wealth. While the benefit to large families can be claimed by the self-employed as well (unlike the contributory family allowance), the only scheme providing universal support to children is the income tax credit for dependent children. Since 2001, the tax credit rises with the number and age of children, while it moderately decreases beyond a certain level of taxable income.

${ }^{13}$ For expositional purposes, the estimates of the FGT index reported in the paper have been multiplied by 100. 
In Spain, families with children below 18 may be eligible for income-tested child benefit. The benefit is targeted at families with very low incomes, though the income threshold increases with the number of children. Approximately 13 per cent of all children received this benefit in 2001. On the other hand, child tax deductions in Spain until 1998 took the form of a non-refundable child tax credit that rose more than proportionally with the number of children. In 1999, the tax credit was replaced by a child tax allowance (i.e. a reduction of taxable income rather than of tax due), whose level per child rises with the number and diminishes with the age of children. In 2003, a refundable tax credit to working mothers was introduced for working women with children aged less than 3.

In Portugal, assistance to families is provided under the "child and youth family benefit" programme. Benefit rates are inversely related to family income. Income brackets are set at multiples of the minimum wage. Within each bracket, allowances vary by the age and number of children. Moreover, special supplements apply in case of disability. While eligibility for the "child and youth family benefit" is limited to children of dependent workers covered by social insurance, the scheme is open to the self-employed on a voluntary basis. Low-income families without social insurance coverage may have access to the child benefit provided they meet a more stringent income test. Furthermore, a system of tax credits for dependent family members operates within the income tax system: each tax unit may credit a certain amount per dependent family member against its gross tax liability.

Not all of the above programmes were taken into consideration in assessing the impact of family transfers on child poverty later in the paper. Table 5 shows the programmes that did exist in 1998, while a policy update is provided in Table A.1 in the Appendix.

[TABLE 5]

The above brief accounts of family transfer arrangements in southern Europe indicate that, in spite of a certain degree of institutional variation, common trends are not hard to identify. This is brought out more clearly in Table 6, where stylised entitlements to cash benefits and tax relief are presented. Various points at the income scale ( $€ 5000, € 10$ $000, € 25000$ and $€ 100000$ per annum in 1998) are taken as yardsticks for families with one, two and three children.

\section{[TABLE 6]}

The amount of assistance per child provided through cash benefits rises with the number of children in Greece, but this effect is less clear in Italy, while the structure of benefits remains invariable in Portugal and especially in Spain. On the other hand, benefit levels are inversely related to income, at least over a certain range, with the exception of Greece where such effect is less consistent. In Spain, benefits are withdrawn fully at relatively low levels of income. In Italy, low-income families with one or two children risk being ineligible for benefit, while the amount of assistance seems to be maximised at the $€ 10000$ income mark, as it then declines steeply. In Portugal, benefits decline gently as income rises. In both I taly and Greece, the structure of transfers leaves a large number of children in low-income families exposed to poverty. The fragmentation of contributory allowances along occupational lines adds quite an exceptional element of regressivity in the allocation of family transfers.

Turning to the treatment of dependent children by the income tax system, regressive outcomes seem to be the rule. To start with, low-income families on derive little or no benefit from the child tax relief, as they would have paid little or no income tax in any case. At this income level, irrespective of the number of children, tax relief is entirely worthless in Italy and Spain, while the resulting gross tax liability is lower than the tax credit itself in Greece and Portugal. In general, as families begin to pay tax, the per child value of child tax relief increases and then remains constant in all four countries. Overall, income transfers to families with children are even less generous through the tax system than through social security, with the exception of Spain. There a clear dichotomy seems to apply: taxpayers are entitled to tax relief for dependent children but not to family 
cash benefits, while low-income families with children are entitled to cash benefits but not to tax relief.

The discussion of the effects of policy changes after 1998, reference year for this paper, is clearly beyond its scope. Nevertheless, stylised entitlement to family transfers in 2003 is shown in Table A.2 of the Appendix. A comparison with the figures reported here in Table 6 shows that in Portugal entitlement to cash benefits improved uniformly since 1998. Nevertheless, this was true for larger low-income families in Italy and in Spain, while benefit increases favoured higher-income families with three children or more in Greece. Changes to the structure of tax relief for dependent children brought about large gains to families in the upper part of the income scale in Italy and in Spain (specifically middle-income families in Italy and high-income families in Spain). The value of tax relief increased less markedly in Greece and in Portugal, where it remained flat with respect to income.

Stylised entitlement is heavily dependent on underlying assumptions, especially where (as in Greece and, to some extent, in Italy) coverage is fragmented. As a result, the emerging picture may be partly driven by the choice of cases for which entitlements are calculated. This is not an issue if estimated entitlement is generated by the model itself. Average values of family transfers for 12 family types are shown in Table 7.

\section{[TABLE 7]}

Table 7 is different from Table 6 in various other respects as well. To start with, an extra dimension has been added as regards the number of children in the family $(4+)$. Moreover, the family income groups are defined in terms of average full-time earnings of male employees in each country. For example, "middle" income is defined as falling in the range of $75 \%$ to $175 \%$ of average earnings, while "low" and "high" incomes are defined as being below or above that range respectively. Furthermore, using microsimulation to estimate entitlement enables certain interactions to be taken into account that were ignored before. For instance, receiving benefit increases disposable income which may lead to more tax being paid, family benefits may be taxed etc.

Despite these differences, many of the earlier findings are confirmed. Cash benefits are more substantial than tax relief, except for middle to high income families in Spain. The value of cash benefits diminishes with income, though not as clearly in Greece. Tax relief favours higher-income families. The value of family transfers increases with the number of children.

The analysis of entitlements at various levels of income and family size presented above raises important questions about the distributional impact of family transfers in southern Europe. Offering answers to such questions requires a more systematic analysis of the incidence of family transfers by income group. This is explored in the next section.

\section{Family transfers and child poverty}

What is the distributional impact of existing arrangements of family transfers in southern Europe? This section presents detailed empirical evidence on this question drawing on estimates produced with the European tax-benefit model EUROMOD. A comparison with official estimates of child poverty and distributive impact of social transfers is presented in section 5.2 .

\subsection{Distributional impact of family transfers}

Table 8 shows the incidence of total expenditure on family cash benefits and child tax relief separately by decile of equivalent disposable income in each of the four countries. Cash benefits to families in Spain and in Italy seem to target the bottom of the income distribution, as the four poorest deciles account for approximately 97 and 85 per cent of all benefit respectively. Conversely, the proportion of total expenditure received by the 
four richest deciles is 1 per cent in Spain and 4 per cent in Italy. This effect is less marked in the case in Portugal and reversed in that of Greece: while in the former the ratio of total benefit received by the four poorest and the four richest income deciles is 46 to 33 per cent, in the latter it is 37 to 44 per cent (i.e. more benefit to higher-income families).

\section{[TABLE 8]}

In contrast, child tax relief tends to be more evenly distributed among taxpayers (that is, except to lower income groups). As a matter of fact, the ratio of the amount received by the upper half of the distribution relative to that received by the bottom half is 1.8 in Greece, 1.4 in Portugal and 1.1 in Spain, while in Italy the distribution of tax relief is skewed in favour of lower incomes.

Table 9 shows the incidence of family cash benefits and child tax relief by decile in terms of income share. Focusing on the poorest decile alone, cash benefits contribute about 1 per cent of total family income in Greece, 3 per cent in Spain and in Portugal, 6 per cent in Italy. Except in Italy (over 2 per cent), the relative value of tax relief to the bottom decile is negligible. On the whole, the distribution of cash benefits to families by income group seems to be more strongly progressive in Italy and, to some extent, in Portugal. In Spain, family cash benefits make an appreciable contribution to the incomes of families in the lowest decile, but taper off rapidly as income rises.

\section{[TABLE 9]}

The income share of child tax relief is much lower everywhere. Except in Italy, families in the bottom decile take little advantage of tax relief compared to those immediately above them in terms of income. Overall, the weight of tax relief is lower than that of cash benefits everywhere except in Spain. All these findings are in line with the previous discussion of entitlements.

Such variations between countries are vividly depicted in Graph 1. The graph contains four lines: the concentration curves of family cash benefits, child tax relief, all family transfers taken together and equivalent disposable income (net of family transfers), when the members of the population are ranked in ascending order according to their equivalent disposable income (before family transfers). The concentration curves depict the cumulative distribution of the corresponding variables. Since the members of the population are ranked according to their equivalent disposable income, the concentration curve of equivalent disposable income (net of family transfers) is the Lorenz curve of this distribution. Furthermore, the (diagonal) line of perfect equality is also depicted in the graph for expositional purposes. Since cash benefits are more important than tax relief in Greece, Italy and Portugal, the location of the concentration curve of all family transfers taken together in these countries is determined to a large extent by the location of the concentration curve of cash benefits. The opposite is observed in Spain, where the income share of cash benefits is relatively low.

\section{[GRAPH 1]}

In Greece, where cash benefits are most spread across the entire income distribution than in the other countries, the corresponding concentration curve is very close to the diagonal. In the other countries, the concentration curve of cash benefits lies above the diagonal. In fact, in the cases of Italy and, especially, Spain these concentration curves follow closely the top left corner of the graph, thus implying that these highly concentrated benefits are likely to be very progressive (especially in Italy, where cash benefits are quantitatively more important).

In all countries apart from Italy the concentration curve of tax relief lies below the diagonal. Actually, due to the fact that the poorest households do not benefit from tax relief in Greece, Spain and Portugal, in these countries the concentration curve of tax relief crosses the Lorenz curve close to the bottom of the distribution. Therefore, unlike 
Italy, the progressivity of the distributional effect of tax relief in these countries cannot be determined a priori.

When all family transfers are taken together, the corresponding concentration curves in all countries lie above the Lorenz curve, thus implying that these transfers reduce aggregate inequality. However, it should be noted that in Portugal, Spain and, especially, I taly the concentration curve lies above the line of perfect equality, whereas in Greece it lies below it. Therefore, it can be argued that in comparative terms these transfers are less well-targeted towards the poorest segments of the population in Greece than in the rest of the countries under consideration.

Table 10 presents the income share of family transfers and the average transfer per child by household type. In relative terms, the household types whose income increases the most after family transfers are couples with three or more children, followed by single parents with younger children. In absolute terms, the value of family transfers per child rises with the number of children in Greece and, to a lesser extent, in I taly, but the opposite is true in Portugal, while the corresponding profile is flat in Spain.

[TABLE 10]

Nevertheless, the most striking finding is that the overall value of family transfers in southern Europe is extremely low. For instance, couples with one or two children (i.e. the two family types that account for 55 per cent of all children in the four countries as a whole) seem to receive about $€ 6$ per child per month in Spain and in Greece, about $€ 12$ in Portugal and no more than $€ 19$ in Italy ${ }^{14}$.

The impact of family transfers on child poverty by household type is shown in Table 11. The figures can be interpreted as the proportional reduction in the number of children below the poverty line (left-hand panel) and in aggregate child income gap (right-hand panel) due to family transfers.

In terms of headcount poverty, family transfers reduce the number of poor children by 19-21 per cent in Portugal and in Italy, and by 7-8 per cent in Spain and in Greece. With respect to household types, family transfers are more effective at taking children out of poverty if these live in large families. On the contrary, the anti-poverty performance of family transfers as regards one-child families is below average in I taly and disappointing in the other three countries: a proportional reduction of merely 6 per cent in Portugal, 3 per cent in Spain and no reduction at all in Greece.

[TABLE 11]

A similar picture emerges in terms of income gap ratios. On the whole, the aggregate child poverty gap (before family assistance) is reduced by 37 per cent in Portugal, 28 per cent in Italy and 11-12 per cent in Greece and in Spain. This reduction is greatest among families with three children and lowest among those with one child only.

As explained earlier, family transfers have two components: cash benefits and tax relief. What is the relative contribution of each to the reduction of child poverty? An answer to that question is provided in Table 12. In terms of poverty rates, the impact of tax relief appears to be rather negligible, not exceeding a 1.2 percentage point reduction (in Spain). By contrast, family cash benefits seem to be most effective in Portugal and in I taly (a reduction of over 5 percentage points), much less in Greece ( 1 percentage point) and almost not effective at all in Spain. Overall, in comparison to what their level would have been in the absence of family transfers, child poverty rates are 6 percentage points lower in Portugal and in Italy, but less than 2 points lower in Greece and in Spain.

\section{[TABLE 12]}

The results obtained by focusing on the Foster-Greer-Thorbecke index $(a=2)$, attaching a greater value to income changes at the bottom of the distribution, shed more light to the

\footnotetext{
${ }^{14}$ Low sample size seems to affect the estimates for some household types, as in the case of lone parent with at least one older child (i.e. aged over 18) in Italy.
} 
distributional impact of family transfers. Tax relief has a negligible impact on the index, causing a proportional reduction ranging from 5 per cent in Portugal and in Italy to 1-2 per cent in Greece and in Spain. In contrast, the corresponding reduction achieved by cash benefits is much stronger: 44 per cent in Portugal, 27 per cent in Italy, 14 per cent in Spain and 11 per cent in Greece. In fact, the case of Spain offers an illustration of the limitations of a policy approach looking at the headcount rate alone: while tax relief lifts more children over the poverty line than cash benefits, its distributional impact further down the income scale as measured by FGT $(a=2)$ is much weaker.

Finally, the Gini coefficient for the population as a whole registers very little movement as a result of family transfers, with the proportional decline in inequality being highest in the case of Italy (2.8 per cent). Detailed examination of the results shows that they are broadly as anticipated on the basis of the evidence presented in Graph 1.

\subsection{Comparison with official statistics}

How do these estimates compare with official statistics on child poverty? Table A.3 in the Appendix presents the most widely used of such statistics, produced by Eurostat based on the results of the European Community Household Panel ${ }^{15}$.

A comparison of EUROMOD estimates presented in Tables 2 and 12 here with Eurostat figures reproduced in Table A.3 in the Appendix would conclude the following. In terms of baseline estimates of child poverty, EUROMOD figures are broadly in line with Eurostat ones with respect to Greece, but seem to overstate child poverty by about 4 percentage points in Italy and understate it by a similar margin in Spain and Portugal. In terms of distributional effect of family transfers, the main finding is that Eurostat estimates show it to be much weaker in the case of I taly than according to the results presented here. How can these differences be accounted for?

On the whole, as explained in section 2 earlier, the dataset incorporated in EUROMOD is "synthetic". The original data for the four countries of southern Europe refer to the year 1995 (Greece and Italy) or 1996 (Spain and Portugal). Income data were then updated to the year 1998, the policy year for our analysis ${ }^{16}$. Moreover, while in three of the four countries the original data were drawn from the European Community Household Panel, data from the Bank of Italy Household Income Survey were used for the model of that country. A further cause for discrepancy might be the definition of children as individuals below 16 in Eurostat documents, instead of individuals aged 0-17 as in this paper.

On the other hand, more general issues arise from the fact that tax-benefit models are fundamentally different to common datasets. In the latter social transfers can be read off the data, in the former they are simulated by the model itself. Furthermore, Eurostat defines social transfers excluding tax relief, which forms a crucial element in the analysis in this paper. Finally, as explained earlier, our estimates rest on the assumption of full take up of social transfers. Actual take up may well be less than complete, although the extent of the problem in the case of family transfers in southern Europe remains a mute point ${ }^{17}$. Note that the failure to account for non-take up in EUROMOD and the failure to include tax relief in Eurostat statistics introduce biases that may partly offset each other.

\subsection{Target efficiency of family transfers}

The preceding discussion of anti-poverty effectiveness raises an obvious question: are family transfers in southern Europe well targeted? The term "target efficiency" is often

\footnotetext{
${ }^{15}$ For a more thorough comparison of EUROMOD baseline estimates with those derived from national statistical sources and the ECHP see Mantovani \& Sutherland (2003).

${ }^{16}$ More details on the updating process can be found in the relevant country reports in the EUROMOD website (http://www.econ.cam.ac.uk/dae/mu/emodcty.htm). The model is being currently updated for the year 2001.

${ }^{17}$ For a treatment of non-take up in the context of microsimulation see Sutherland (2003).
} 
used loosely, especially in the policy debate. However, it can be formally measured through a set of indicators. For the purposes of this paper, four indicators are estimated. Vertical expenditure efficiency (VEE) measures the share of total benefit received by individuals below the poverty line. As seen in Figure 1, $V E E=(A) /(A+B+C)$. Poverty reduction efficiency (PRE) is the fraction of total expenditure allowing poor individuals to approach or reach - but not cross - the poverty line. PRE is shown as $(A) /(A+B+C)$. The spillover index (S) is a measure of the excess of expenditure relative to the amount strictly necessary to reach the poverty line, defined as $(B) /(A+B)$. It can be seen that $\operatorname{VEE}(1-\mathrm{S})=$ PRE.

\section{[FIGURE 1]}

The three measures considered so far are useful in measuring vertical efficiency or the extent to which total benefit is received by those below the poverty line alone. However, vertical efficiency cannot evaluate the effectiveness of a programme in fighting poverty. A transfer may be efficient in the sense that it is overwhelmingly targeted on the poor, but may fail to reach all those below the poverty line or its level may be too low to raise the living standards of beneficiaries significantly. This latter aspect is better captured by poverty gap efficiency (PGE), an indicator of horizontal efficiency, measuring the extent to which the transfers succeed in filling the aggregate poverty gap ${ }^{18}$. PGE is equal to $(A) /(A+D)$. The poverty gap itself can be either unweighted, when the parameter a of the FGT index is set equal to 1 , or weighted to indicate greater concern for the condition of the poorest (higher values of a). All four indicators of target efficiency are presented in diagrammatic form in Figure 1.

The results of our estimation of target efficiency with respect to child poverty, separately for each class of family transfers (cash benefits and tax relief), can be seen in Table 13.

\section{[TABLE 13]}

In terms of vertical efficiency, as measured by PRE, family cash benefits seem to be best targeted in Spain ( 80 per cent of total expenditure). Targeting is less efficient in Italy ( 55 per cent of total expenditure), in Portugal ( 39 per cent) and in Greece ( 21 per cent). Child tax relief is clearly not targeted. In Italy, more than 75 per cent of all tax relief for dependent children is aimed above the poverty line. In the other three countries, the equivalent figure is closer to the 90 per cent mark. The other two indicators of vertical efficiency, VEE and S, reiterate the point presenting a similar picture.

Our estimates are much less reassuring in terms of horizontal efficiency, as measured by PGE. The reduction of the unweighted aggregate poverty gap $(a=1)$ caused by family cash benefits ranges from a low but significant of 21 per cent in Portugal and 15 per cent in Italy, to a rather disappointing 5 per cent in Spain and Greece. Obviously, attaching greater weight to the improvement of lowest incomes increases the value of the index: for $a=3$, the reduction of weighted aggregate poverty gap is 40 per cent in Portugal, nearly 20 per cent in Italy and just over 10 per cent in Greece and in Spain. In contrast, the anti-poverty impact of tax relief remains negligible in all cases.

Summing up the evidence on target efficiency presented here, two findings stand out. On the one hand, in terms of both vertical and horizontal efficiency family cash benefits are better targeted than child tax relief. It is clear that the non-refundable nature of the latter renders it unsuitable as mechanism of income support to the poorest. On the other hand, family transfers as a whole are better targeted in I taly and Portugal. In the case of Greece, current policy seems to fail low-income families with children on both counts. In Spain, cash benefits appear to exemplify the textbook case of stringent means-testing: reserved for the poorest families alone, but not nearly adequate enough to improve their living standards significantly.

\footnotetext{
${ }^{18}$ In general, vertical efficiency measures poverty reduction due to a benefit as a proportion of all spending on that benefit. Instead, horizontal efficiency measures poverty reduction as a proportion of pre-benefit poverty. For an early analysis see Beckerman (1979).
} 
To conclude: existing family transfer programmes in southern Europe seem to perform at best modestly in terms of poverty reduction. The implication of this finding is that the scope for improving the redistributive performance of income transfers to families with children through redesigning the structure of benefits is ample. This is examined next.

\section{Reforming family transfers}

It was earlier established that a common feature of actual family transfer programmes throughout southern Europe is that many families with children at risk of poverty are left with little or no income support. An obvious - though far from uncontested - solution to the problem of coverage gaps is the introduction of a universal child benefit. From the point of view of this paper, such an approach has the extra advantage that it is easy to explain and simple to simulate. For the sake of good policy design, not to mention fiscal prudence, such a benefit is assumed to substitute (rather than be added on to) existing family transfer programmes.

What would be the implications of a universal child benefit, introduced at the same time as actual programmes of family transfers are abolished? Using a tax-benefit model like EUROMOD enables us to provide specific answers to the effect of such a policy change.

Universal child benefits appear straightforward enough. However, one still has to define parameters such as the value of benefit and eligibility conditions with respect to age. In this section, five variations to the general theme are explored. All five involve replacing existing family transfers for children aged 0-17 by a universal child benefit. In the case of reforms I-II, the (flat) rate of benefit in each country has been chosen so as to match existing family transfers exactly in terms of impact on child poverty and on fiscal costs respectively, i.e. they are "poverty neutral" and "budget neutral".

Reforms III-V simulate "actually existing" child benefits: the British, Danish and Swedish schemes respectively. The three schemes were chosen to illustrate the effect of different benefit structures. The British child benefit scheme pays a higher rate to the eldest child in the family and a single (reduced) rate to all subsequent children. The Danish scheme pays variable rates with respect to age: the benefit rate is highest for children aged 0-3 and falls somewhat for older children. The Swedish scheme is more similar to the British in that benefit rates vary with the number of children in the family, but in reverse: more generous benefits are paid for the third and subsequent children than for the first two. In order to account for variations in living standards, the level of benefit has been chosen so as to be exactly equivalent as proportion of average male full-time earnings. The benefit amount payable under each variation is presented in Table 14.

\section{[TABLE 14]}

Table 15 shows that the anti-poverty impact of universal child benefits, such as the ones simulated here, would be rather mixed. Reform II (budget neutral UCB) would not affect the headcount child poverty rate in Greece, but would increase it by nearly 1 percentage point in Spain and by around 2 percentage points in Italy and in Portugal. Reform IV (Danish CB) would reduce child poverty rates by 1.5 percentage points in Greece and by more than 3.5 points in Italy, Portugal and Spain. The effect of reforms III (British CB) and $\mathrm{V}$ (Swedish CB) would be to reduce headcount poverty in Spain and Greece, raise it in I taly and leave it largely unchanged in Portugal.

\section{[TABLE 15]}

Results for the Foster-Greer-Thorbecke index $(a=2)$ show that the distributional impact of universal child benefits becomes relatively stronger as greater weight is attached to changes at the bottom of the income distribution. Introducing a budget-neutral universal child benefit in place of existing family transfers would have little impact on the FGT index either way. Under reforms III to $V$, the index would fall everywhere except Italy, where it only would under reform IV (Danish CB). The latter would cause a proportional decline of the index by 21 per cent in Greece, 23 per cent in Italy, 28 per cent in 
Portugal and 29 per cent in Spain. The other two reforms, III (British CB) and V (Swedish CB), would reduce the value of the index in Spain (by 19 to 21 per cent), Greece (14-15 per cent) and Portugal (8-10 per cent), but would cause an increase in Italy of ( 12 and 5 per cent under reforms III and $\mathrm{V}$ respectively).

Finally, the estimates reported in the lowest panel of Table 15 suggest that the impact of all reforms on inequality as measured by the Gini index would be less significant. Reform IV (Danish CB) is possibly a partial exception to that rule, reducing income inequality among the child population by 2 per cent in Greece and in Spain, by 1.8 per cent in Italy and by 1.0 per cent in Portugal.

These results make it clear that, provided it is pitched at a level high enough, a universal child benefit could have a strong anti-poverty impact in all four countries. The question then arises: would there be enough political support for such reform in southern Europe? Clearly, the answer to this lies beyond the scope of this paper. However, the distribution of winners and losers following such reform reveals some of the difficulties involved ${ }^{19}$. By way of illustration, our findings for each universal child benefit simulated here by income decile are presented in Tables 16 to 20.

[TABLE 16]

Table 16 shows that a poverty-neutral universal child benefit would leave more winners than losers in all four countries. Nevertheless, this would not be true among low income groups in Spain and in Italy (bottom 20 and 30 per cent of the income distribution respectively). Obviously, a "poverty-neutral universal child benefit" is merely an artefact, simulated as a means to gaining an insight to the likely effects of a switch to a flat-rate child benefit that leaves poverty rates unchanged. In this sense, the results of Table 16 are quite revealing: in those countries where family transfers were found earlier to be better targeted, more individuals below the poverty line would be worse off as a result of such a switch (even if no-one were to cross that line). Note, however, that a universal child benefit of $€ 76$ per month per child (€912 per year is the poverty-neutral rate in Table 14) would still be superior to current family transfers for as many as 32 per cent of individuals in the lowest income decile in Italy.

\section{[TABLE 17]}

Compared to the poverty-neutral reform, a budget-neutral universal child benefit would be less generous in all four countries. Table 17 shows that, following such reform, there would be more losers than winners in Italy (particularly in the bottom 40 per cent of the distribution), while in Spain a majority within all income deciles would be worse off. On the contrary, under reform II, winners would outnumber losers in Greece (except in decile 9, i.e. the second richest) and in Portugal (throughout the income distribution).

Calculating winners and losers under a policy change that is not budget neutral can be misleading, as it raises the question of how the extra cost is to be financed. The obvious answer to that would be "by raising taxes". Funding reforms III to V would most likely raise the number of losers, depending on the incidence of the offsetting tax increase or the public expenditure cut. Various tax policy designs are conceivable and can be easily modelled. While none is in Tables 18-20, the relevant results are still indicative of the effect of benefit generosity on the distribution of gains and losses.

\section{[TABLE 18]}

As a matter of fact, a non-funded reform III (British CB), shown in Table 18, would alter the picture drastically in all four countries. While the balance between winners and losers in Italy would remain tilted towards the latter, albeit by no more than 35 to 30 , there would now be 58 winners to just 1 loser in Spain. Similarly, the margin of winners over losers would be wider than before in Greece (41 to 11) and in Portugal (52 to 6).

\footnotetext{
${ }^{19}$ When calculating winners and losers no attempt was made to distinguish between "heavy" winners or losers from those gaining or losing small amounts as a result of each reform. Setting a threshold of say $€ 1$ per month or $0.5 \%$ of disposable income would "declassify" many of those shown as winners or losers in Tables 16-20.
} 
As might be expected, reform IV (Danish CB) would eliminate losers in Spain and reduce their proportion to less than 5 per cent in Greece and in Portugal. However, compared to the status quo, a significant share of the population in Italy (23 per cent) would remain worse off, though now outnumbered in all income deciles. This is shown in Table 19.

[TABLE 19]

Finally, Table 20 shows that, under reform $V$ (Swedish CB), there would be more winners than losers in all income deciles in all four countries, except in deciles 2 to 4 in Italy. As shown earlier (Table 14), with respect to average full-time male earnings, the Swedish scheme is less generous than the British equivalent for families with one or two children, but its level increases with the number of children in the family.

[TABLE 20]

The discussion of winners and losers under unfunded reforms raises the question of cost. Clearly, the fiscal effect of introducing a universal child benefit would be a function of the level and scope of the benefit itself. However, it would also depend on the demographic profile of each country and the generosity of the family transfer programmes it would replace. The fiscal implications of existing programmes and simulated reforms are all presented in Table 21 below.

\section{[TABLE 21]}

The current cost of family transfers is low: as a proportion of aggregate non-equivalised disposable income, it ranges from 0.5 per cent in Spain to 1.5 per cent in Portugal. The reforms simulated here would be comparatively more costly. Reform IV (Danish CB) would be the costliest of the three, raising expenditure to between 2.1 and 2.6 per cent in all four countries. Reforms III (British CB) and V (Swedish CB) would have a softer fiscal impact, bringing expenditure on income transfers to families with children to between 1.6 and 1.9 per cent of disposable income.

\section{Conclusion}

The purpose of the paper was to evaluate the impact of existing family transfers, taking into account both cash benefits and tax relief, and to simulate the effects of reforms in the shape of variants of a universal child benefit. The results presented above provide useful insights to the question under consideration. These are discussed in turn.

To start with, existing arrangements in this policy area leave much to be desired. Too many poor families with children are ineligible for income support under social security (as is the case in Greece and in Italy) or receive low benefits (as in Spain and to some extent in Portugal). Needless to say, this effect is even more pronounced with respect to tax benefits, as non-refundable schemes exclude poor families by design ${ }^{20}$.

On the other hand, universal child benefits seem to be rather ineffective and quite costly (although, perhaps, more effective and less costly than might have been thought at the outset ${ }^{21}$ ). In general, a trade off between fiscal cost and poverty reduction operates. More generous universal child benefit schemes have stronger distributional impact at a higher fiscal cost. In a sense, this is so obvious it hardly needs mentioning. However, the point is that current expenditure on family transfers is so low in southern Europe that it is unreasonable to expect that a simple reallocation within this policy area would bring about significant improvements in terms of poverty reduction. In view of that, combining

\footnotetext{
20 More recently, refundable tax credit schemes were actually introduced in Greece in 2002 (for low-income families with children aged 6-16 at school) and in Spain in 2003 (for working mothers with children aged below 3 ). Although estimating their effect is a subject of future research, these schemes seem unlikely to alter the regressive nature of tax relief for dependent children in the two countries.

${ }^{21}$ The cost estimates presented in Table 21 do not account for the fact that universal benefits are often taxed as normal income. Taxing benefits progressively would reduce fiscal costs without weakening their anti-poverty impact. On another note, since disposable income is less than gross domestic product, the estimated cost of the reforms simulated here would be a lower proportion of GDP.
} 
a universal (albeit low) income base with more targeted (but non-categorical) policies could be a more effective way to reduce poverty at a reasonable cost to the tax payer.

As explained earlier, the analysis presented here is restricted to income transfers alone. Ignoring benefits in kind and their distributional effect is common practice in current research on incomes and wealth ${ }^{22}$. Although this must be partly driven by convenience, the methodological complexities of accounting for the distributional impact of benefits in kind ought not to be underestimated. Whatever the reason, the omission is regrettable. There can be little doubt that a concerted policy effort aimed to combat child poverty in Europe must assign a higher priority to the universal provision of family services than to that of cash benefits. To mention the most obvious example, good quality and affordable child care to allow mothers to work seems to be a much more promising route out of child poverty than relying on cash benefits alone, however generous.

Naturally, care should be taken to avoid the other extreme, too: family services and cash benefits are complements, not substitutes ${ }^{23}$. A penniless family will always be poor, no matter how broad the range of services it has free access to. In other words, the design of income transfers to families with children matters still.

However, the contest of universal child benefits vs. existing family transfers implied by the results is less than fully fair due to another factor briefly touched upon earlier. The analysis presented here assumes $100 \%$ take up of all benefits. This is known to be a reasonable approximation of the real world with respect to universal benefits alone. As a matter of fact, the take up of means-tested benefits is incomplete, often significantly so. In other words, allowing for non-take up would tilt the balance of the assessment firmly in favour of the universal child benefit programmes simulated here. Furthermore, taking into account other features known to be associated with such programmes (for example, significantly lower administrative costs compared to means-tested benefits) would make universal child benefits look more attractive.

On another note, the headcount rate of poverty is a particularly harsh criterion by which to judge universal benefits. Bringing in the Foster-Greer-Thorbecke index revealed that the redistributive performance of the reforms simulated improved as we moved to a measure implying more concern for families at the bottom of the income distribution.

More broadly, universal benefits can be defended on the grounds that they strengthen work incentives and eliminate the poverty trap, while at the same time promoting wider goals such as individual autonomy and social citizenship. In the case of child benefits, a further argument in their favour is that they function as an instrument of horizontal redistribution from single taxpayers to families with children. If children can be viewed, at least partly, as a public good, then shifting some of their cost to the society at large can be seen as promoting distributional justice.

The final conclusion concerns the methodology applied here. Significant policy questions such as the one posed here ("what would be the effect on child poverty and fiscal costs of a universal child benefit introduced in place of existing programmes of family transfers?") are so complex and to a certain extent counterfactual that cannot be fully answered without recourse to a benefit-tax model such as EUROMOD. Microsimulation models are not immune from limitations of their own, some of which were discussed earlier. Nevertheless, their quite unique advantage is precisely the ability to simulate the impact of policy reforms.

In this sense, the contribution of microsimulation can best be thought as an input in the policy making process: informing policy questions and thereby promoting a more rational and dispassionate political debate on tax-benefit reform. There can be little doubt that these goods are in relatively short supply in southern Europe. Whether this paper appreciably adds to their stock remains to be seen.

\footnotetext{
${ }^{22}$ See Smeeding et al (1993) for an exception to that rule.

${ }^{23}$ For an excellent elaboration of this point see Atkinson (1998).
} 


\section{References}

Alcock P., Glennerster H., Oakley A. \& Sinfield A. (2001) Welfare and well-being: Richard Titmuss' contribution to social policy. Bristol: Policy Press.

Atkinson A.B. (1998) Social exclusion, poverty and unemployment. In: Atkinson A.B. \& Hills J. (ed) Exclusion, employment and opportunity. CASE Paper 4. Centre for the Analysis of Social Exclusion. London School of Economics.

Beckerman W. (1979) Impact of income-maintenance payments on poverty in Britain, 1975. Economic J ournal 89 (354) 261-279.

Brewer M. (2003) The new tax credits. IFS Briefing Note 35. London: Institute of Fiscal Studies.

CEC (2003) Statistical Annex to the Draft joint inclusion report. Commission Staff Working Paper. Published 12 December 2003. Com (2003) 773 final. Brussels: Commission of the European Communities.

Esping-Andersen G. with Gallie D., Hemerijck A. \& Myles J. (2002) Why we need a new welfare state. Oxford: Oxford University Press.

Esping-Andersen G. \& Sarasa S. (2002) The generational conflict reconsidered. Journal of European Social Policy 12 (1) 5-21.

Fernández Cordón J.A. (1997) Youth residential independence and autonomy: a comparative study. Journal of Family Issues (6) 576-607.

Ferrera M. (1996) The "southern model" of welfare in social Europe. Journal of European Social Policy 6 (1) 17-37.

Ferrera M., Hemerijck A. \& Rhodes M. (2000) The future of social Europe: recasting work and welfare in the new economy. Oeiras: Celta Editores.

Ferrera M., Matsaganis M. \& Sacchi S. (2002) Open co-ordination against poverty: the new EU "social inclusion process". Journal of European Social Policy 12 (3) 227239.

Foster J.E., Greer J. \& Thorbecke E. (1984) A class of decomposable poverty measures. Econometrica 52 (761-766).

Ginsborg P. (2001) Italy and its discontents: family, civil society, state 1980-2001. London: Penguin.

Hernanz V., Malherbet F. \& Pellizzari M. (2004) Take-up of welfare benefits in OECD countries: a review of the evidence. OECD Social, Employment \& Migration Working Paper 17. Paris: OECD.

Kamerman S.B., Neuman M., Waldfogel J. \& Brooks-Gunn J. (2003) Social policies, family types and child outcomes in selected OECD countries. OECD Social, Employment \& Migration Working Paper 6. Paris: OECD.

Levy H. (2003) Child-targeted tax-benefit reform in Spain in a European context: a microsimulation analysis using EUROMOD. Working Paper EM2/03. University of Cambridge.

Lewis J. (2001) The decline of the male breadwinner model: the implications for work and care. Social Politics 8 (2): 152-70.

Mantovani D. \& Sutherland H. (2003) Social indicators and other income statistics using the EUROMOD baseline: a comparison with Eurostat and national statistics. Working Paper EM1/03. University of Cambridge. 
Matsaganis M., Ferrera M. Capucha L. \& Moreno L. (2003) Mending nets in the South: anti-poverty policies in Greece, Italy, Portugal and Spain. Social Policy \& Administration 37 (6) 639-655.

Moffitt R. (2002) Means-tested transfer programs in the US. Chicago: University of Chicago Press.

Piachaud D. \& Sutherland H. (2001) Child Poverty in Britain and the New Labour government. Journal of Social Policy 30 (1) 95-118.

Rhodes M. (1996) Southern European welfare states: identity, problems and prospects for reform. South European Society \& Politics 1 (3) 1-22.

Ruxton S. \& Bennett F. (2002) Including children? Developing a coherent approach to child poverty and social exclusion across Europe. Brussels: The European Children's Network.

Saraceno C. (1997) Family change, family policies and the restructuring of welfare. In: Family, market and community: equity and efficiency in social policy. OECD Social Policy Series 21. Paris: OECD.

Smeeding T.M., Saunders P., Coder J., Jenkins S.P., Fritzell J., Hagenaars A.J.M., Hauser R. \& Wolfson M. (1993) Poverty, inequality and living standard impacts across seven nations: the effects of non-cash subsidies for health, education and housing. Review of Income \& Wealth 39 229-256.

Sutherland H. (2003) The take-up of Income Support by pensioners: estimates from POLIMOD using the Family Resources Survey. Microsimulation Unit Research Note 42. University of Cambridge. 



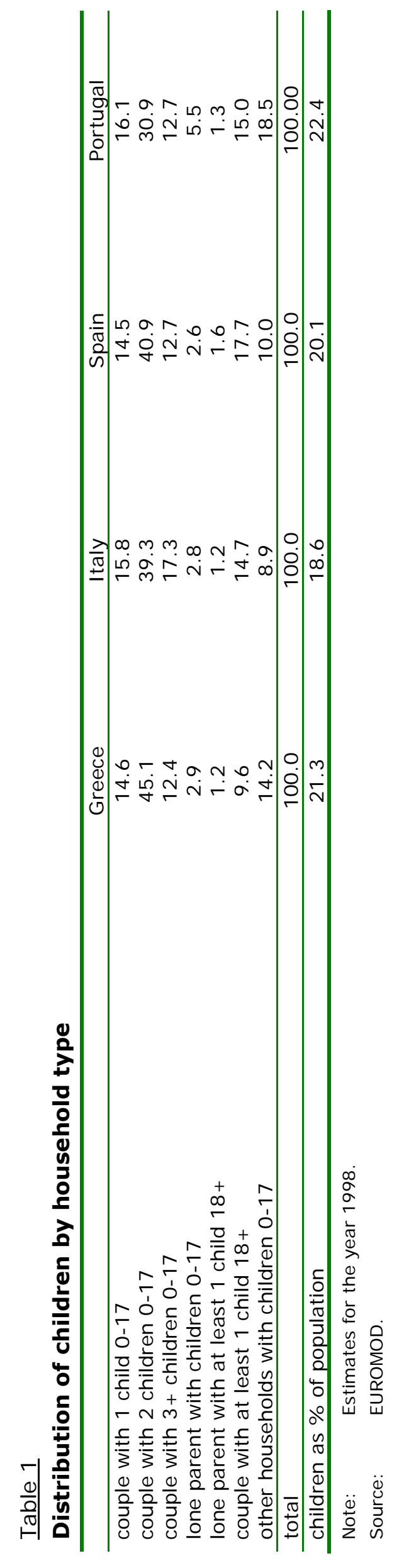




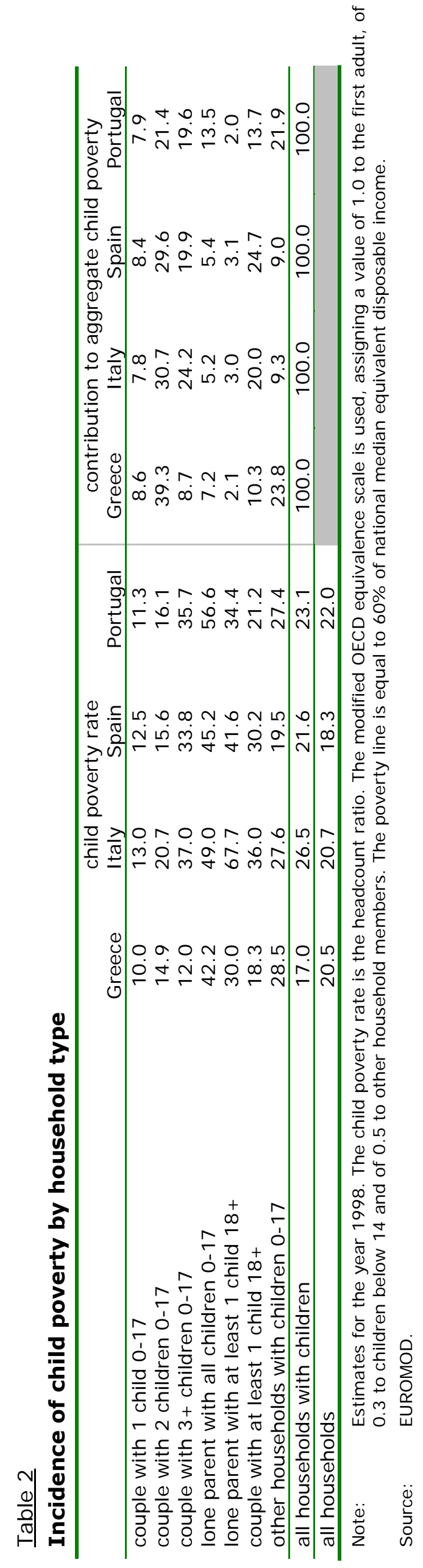




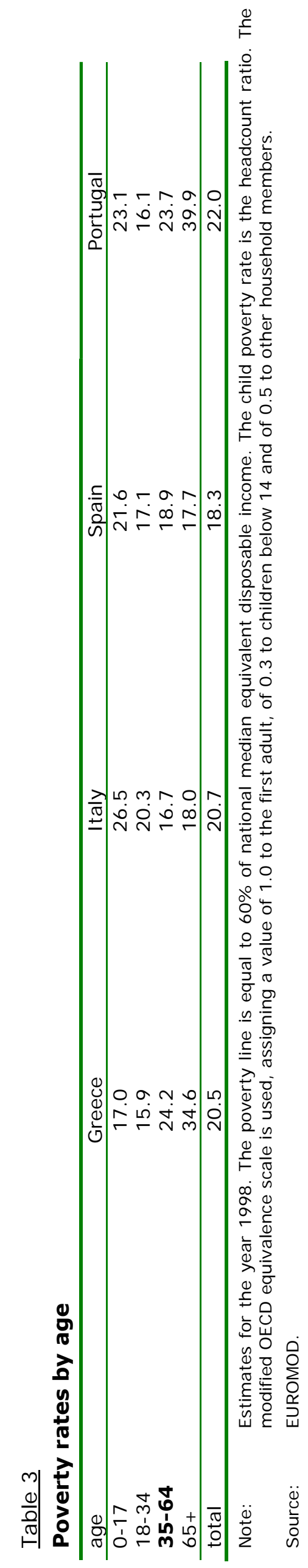




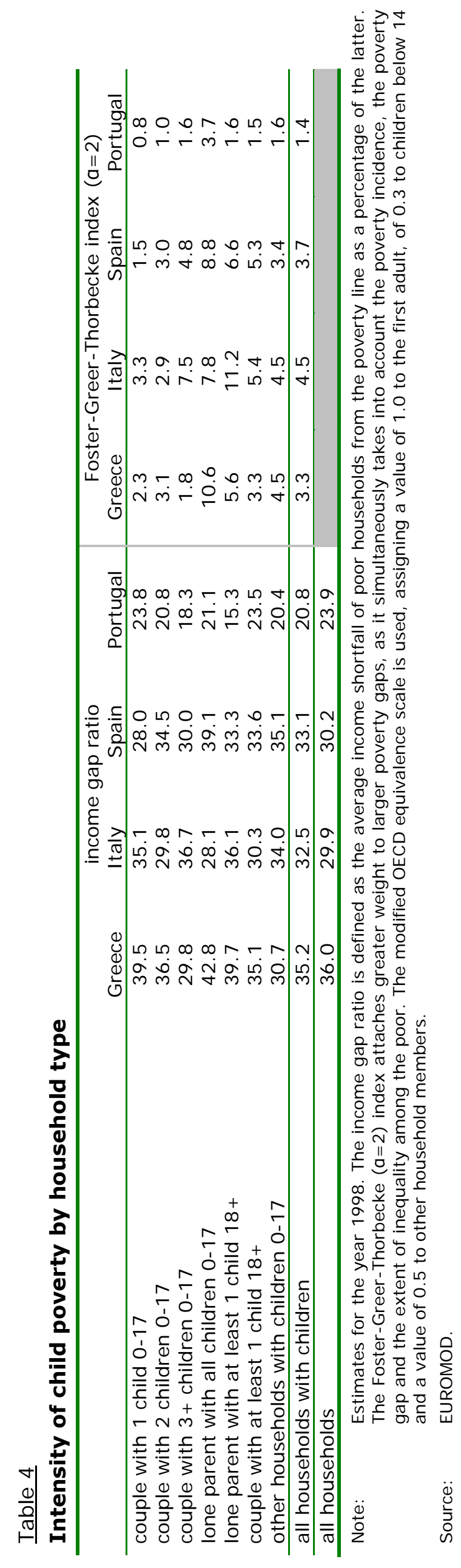




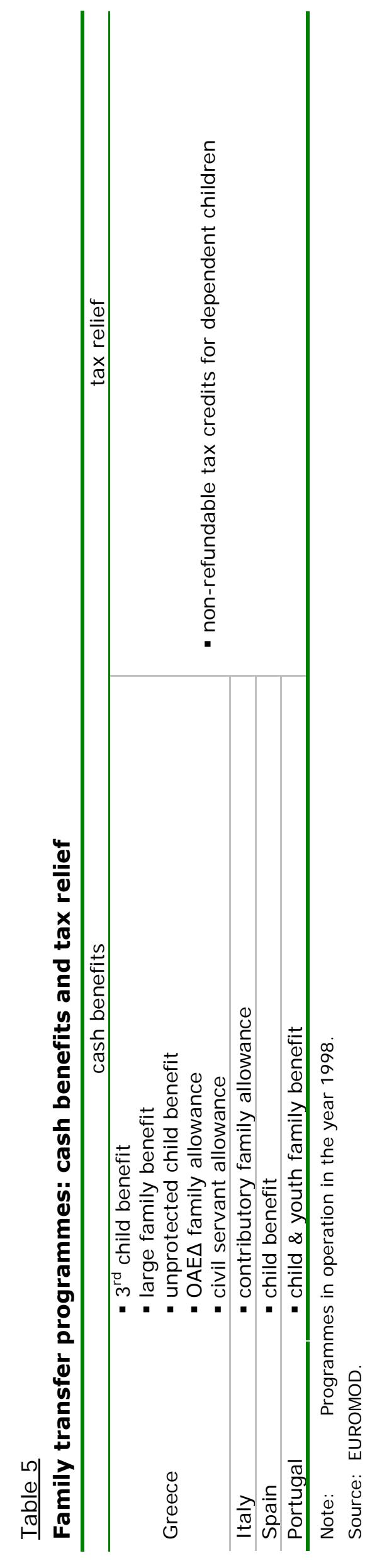

เก 


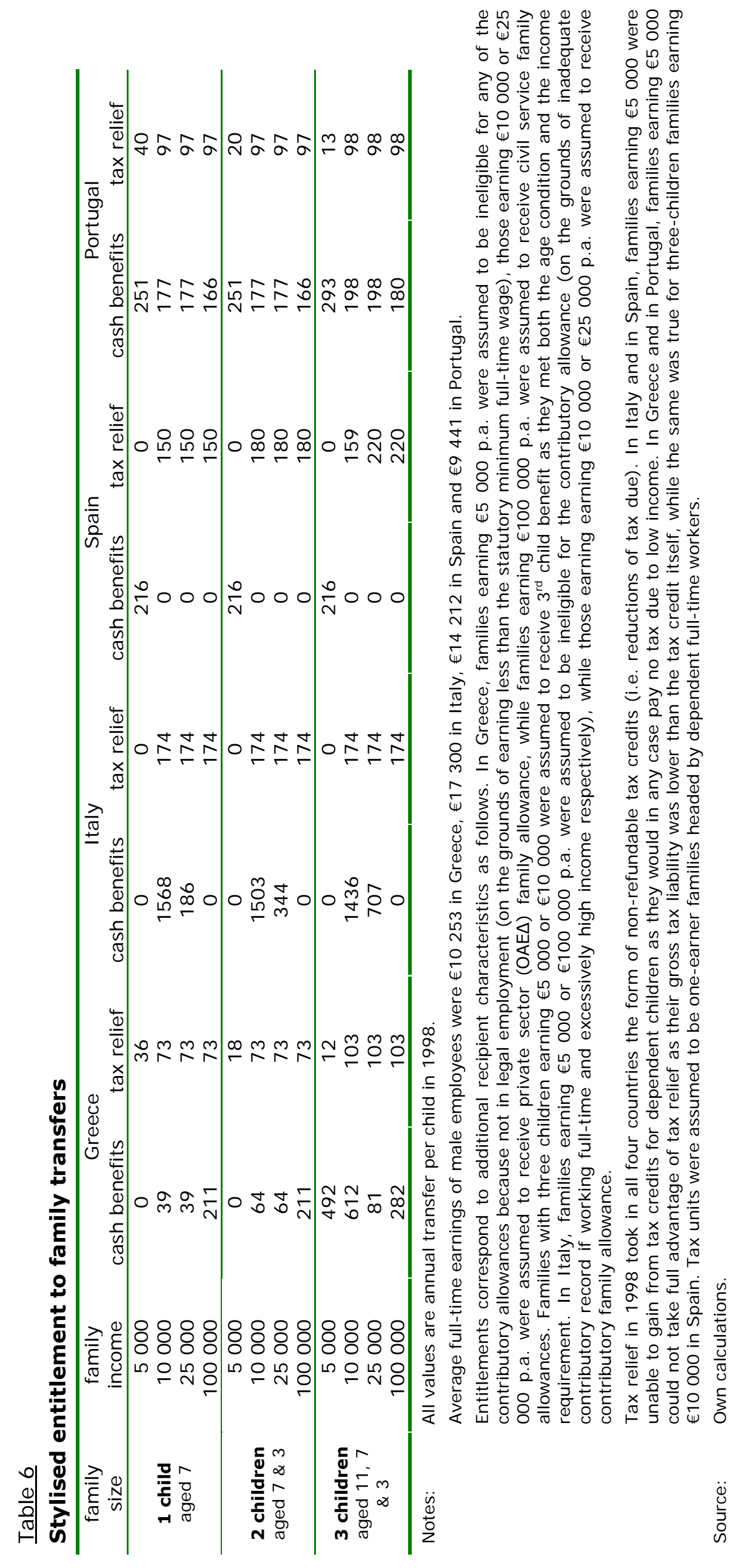




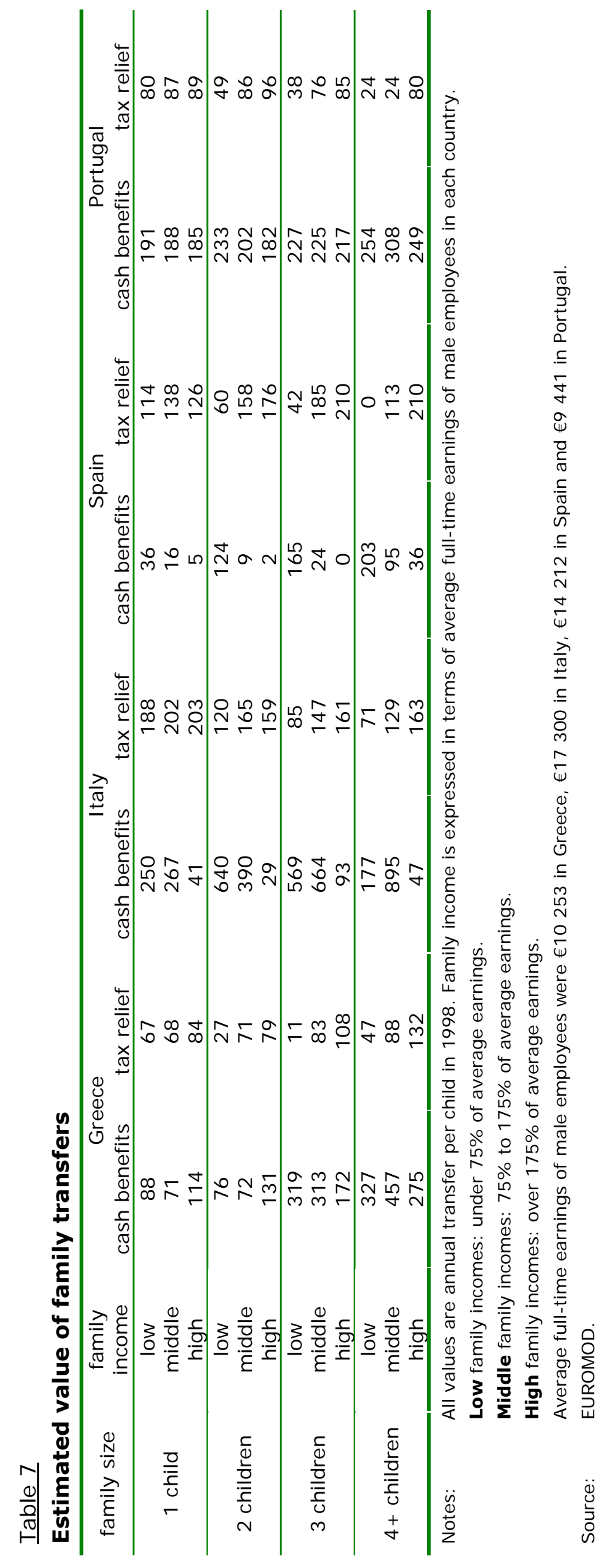




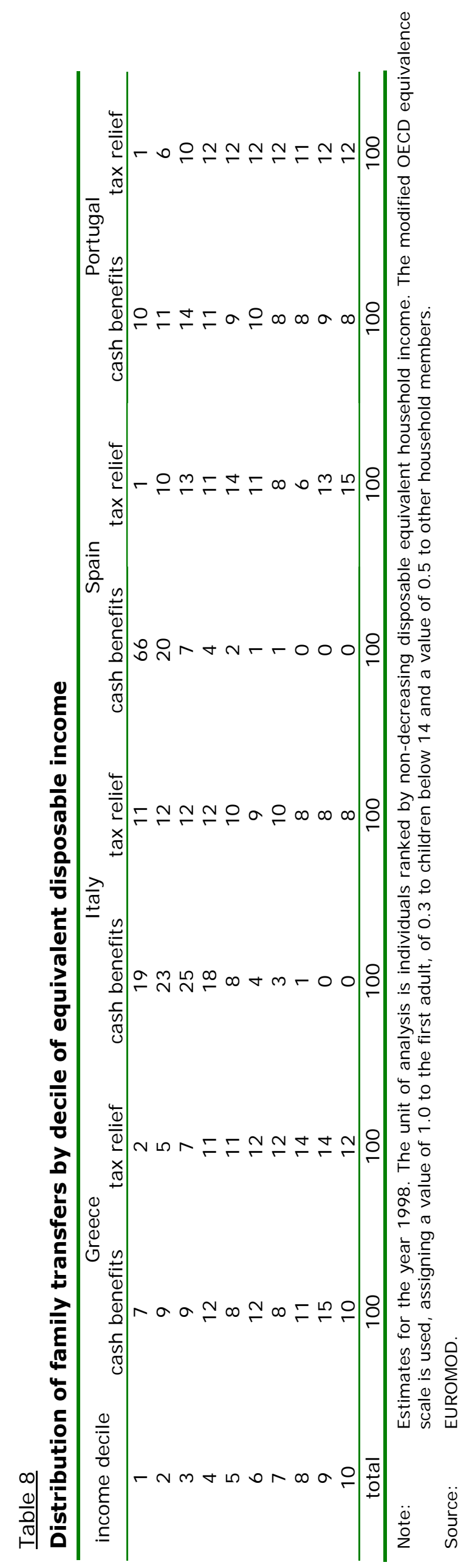




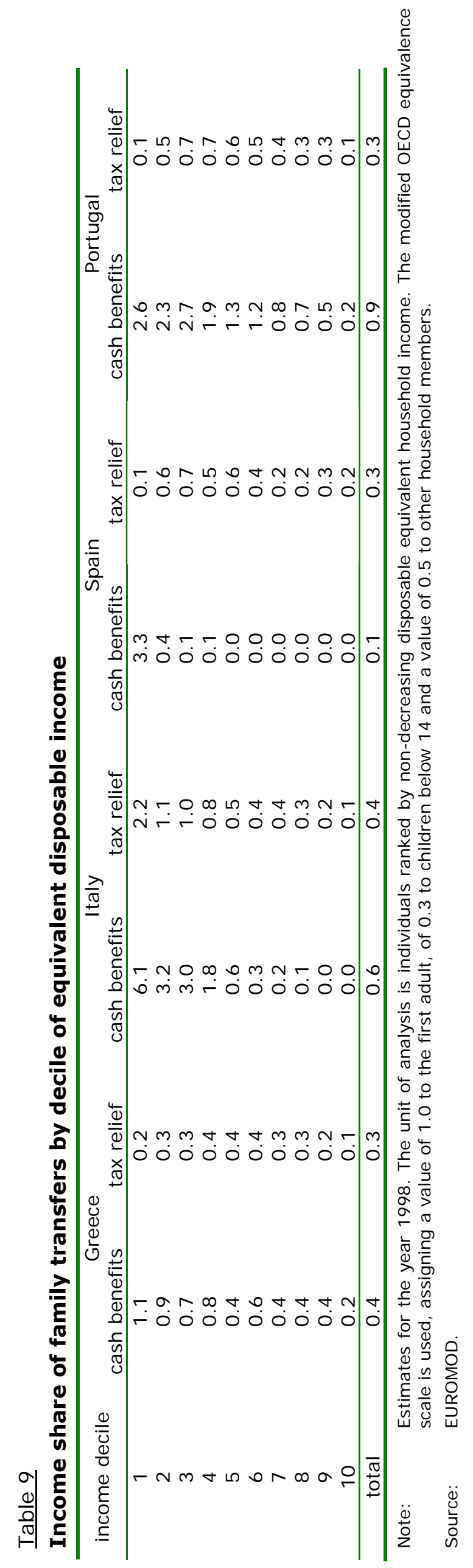




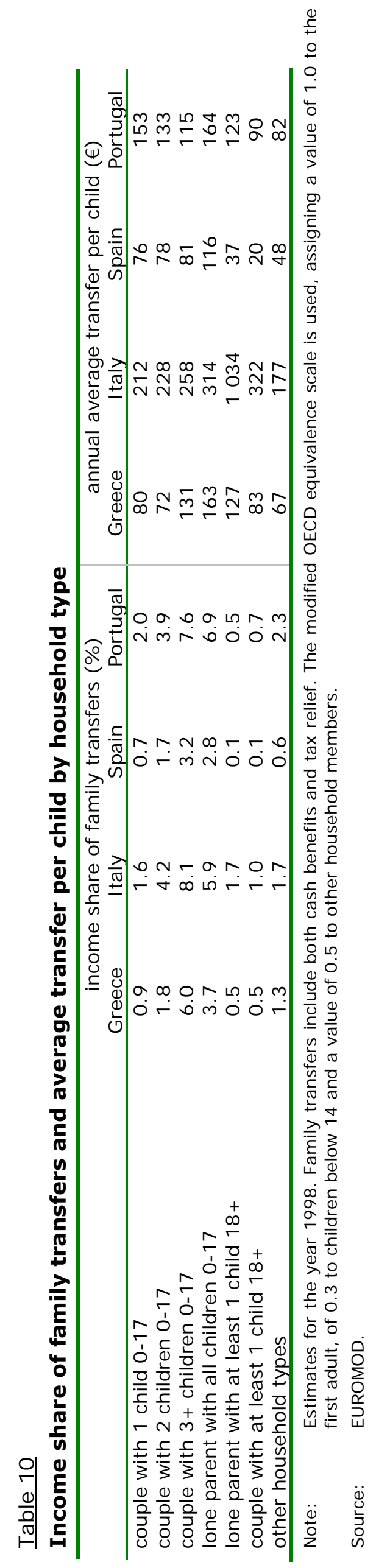




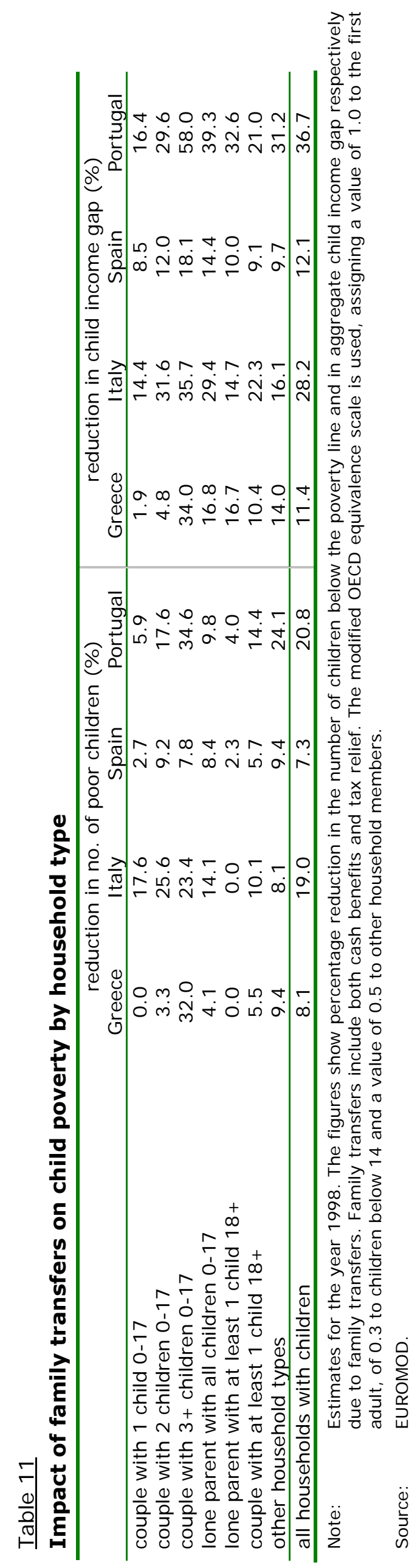




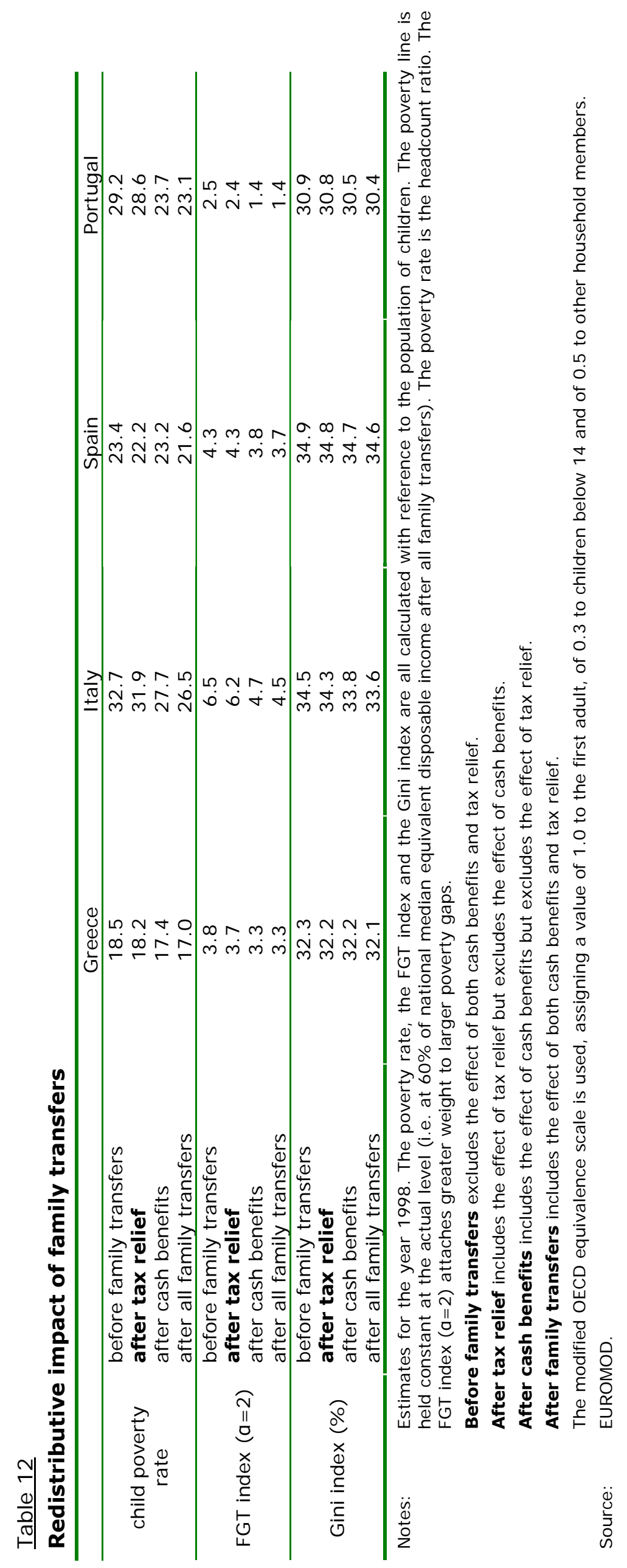




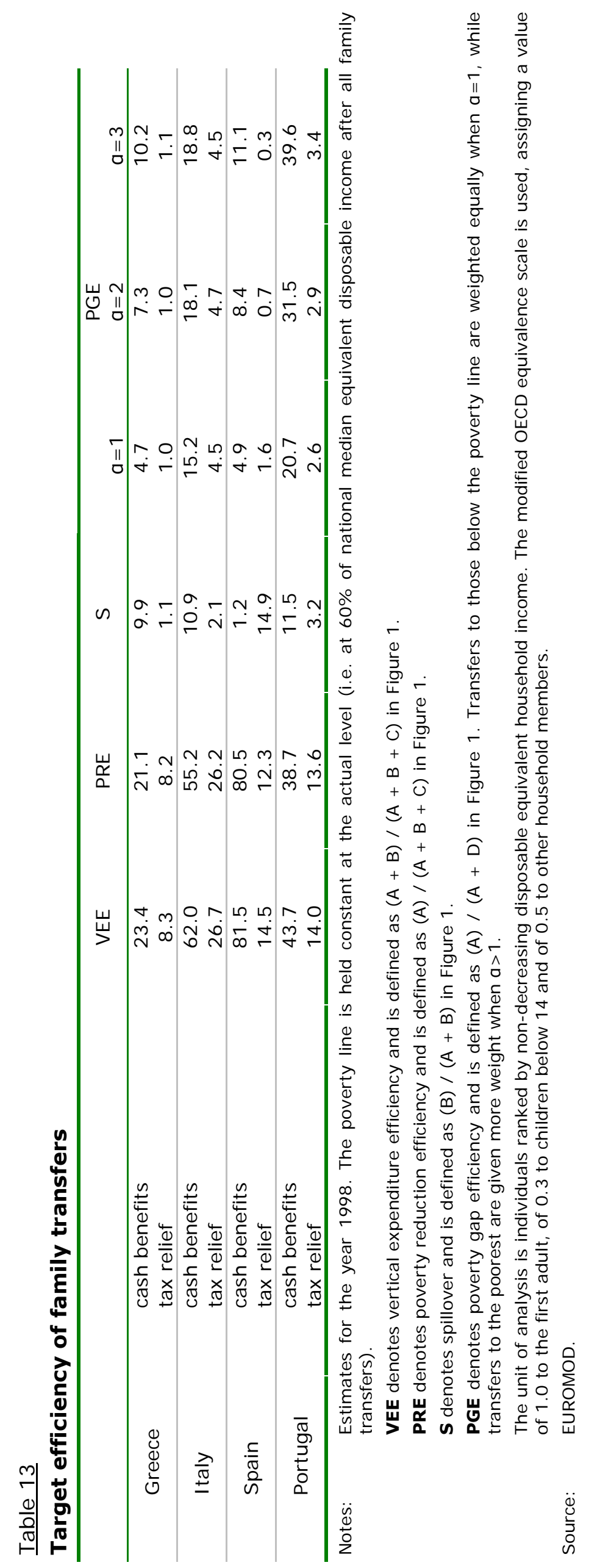




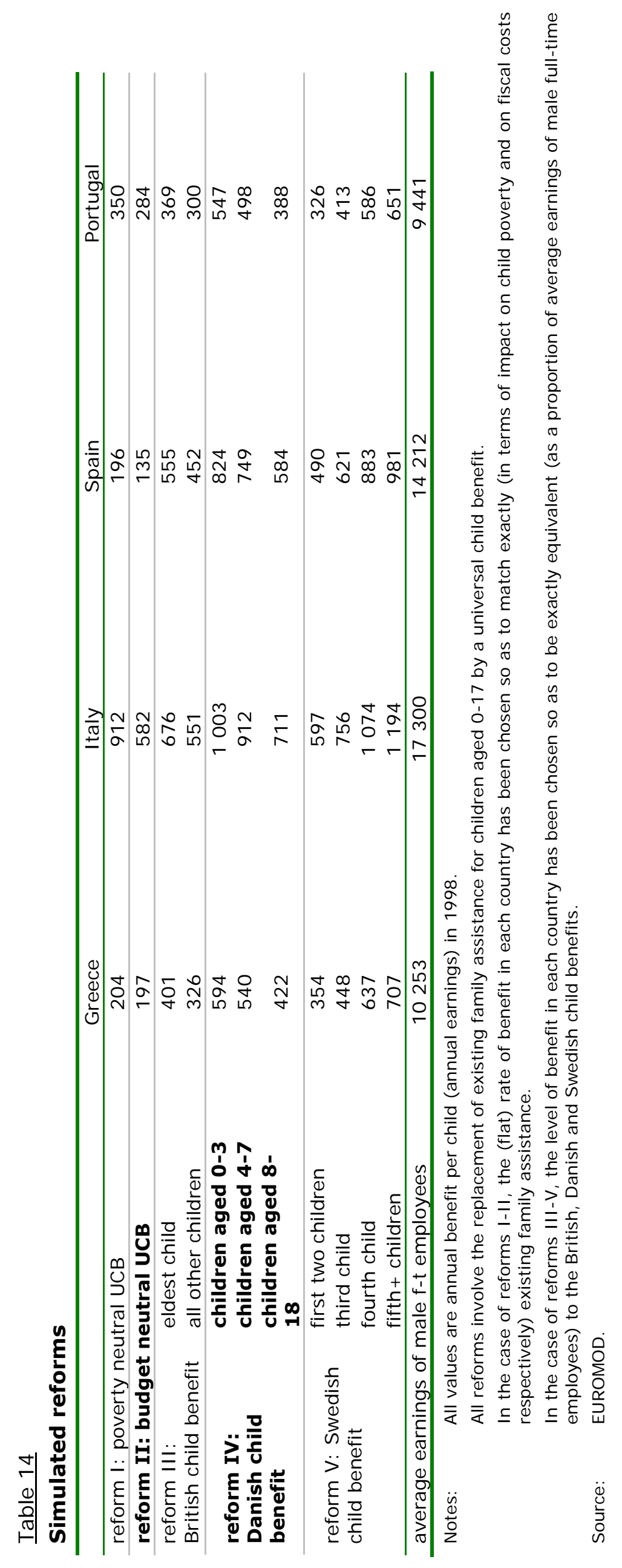




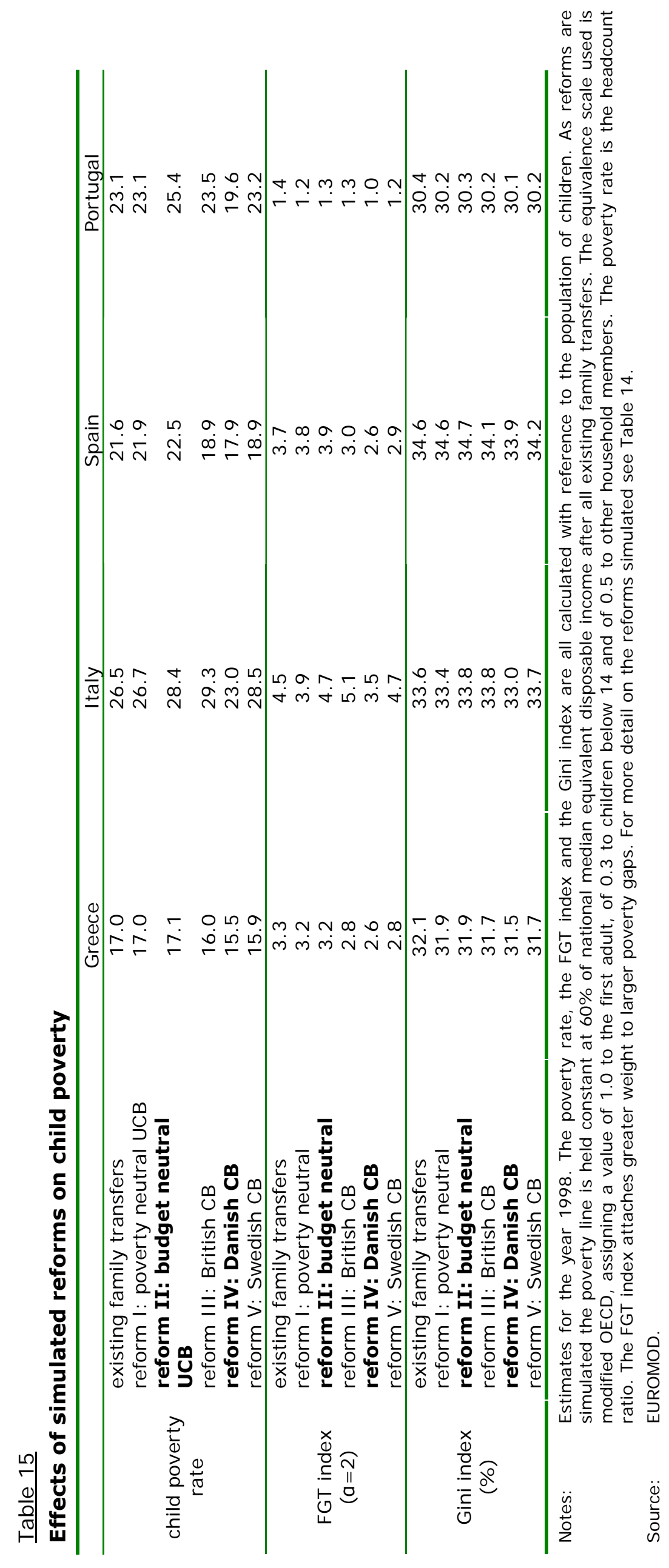




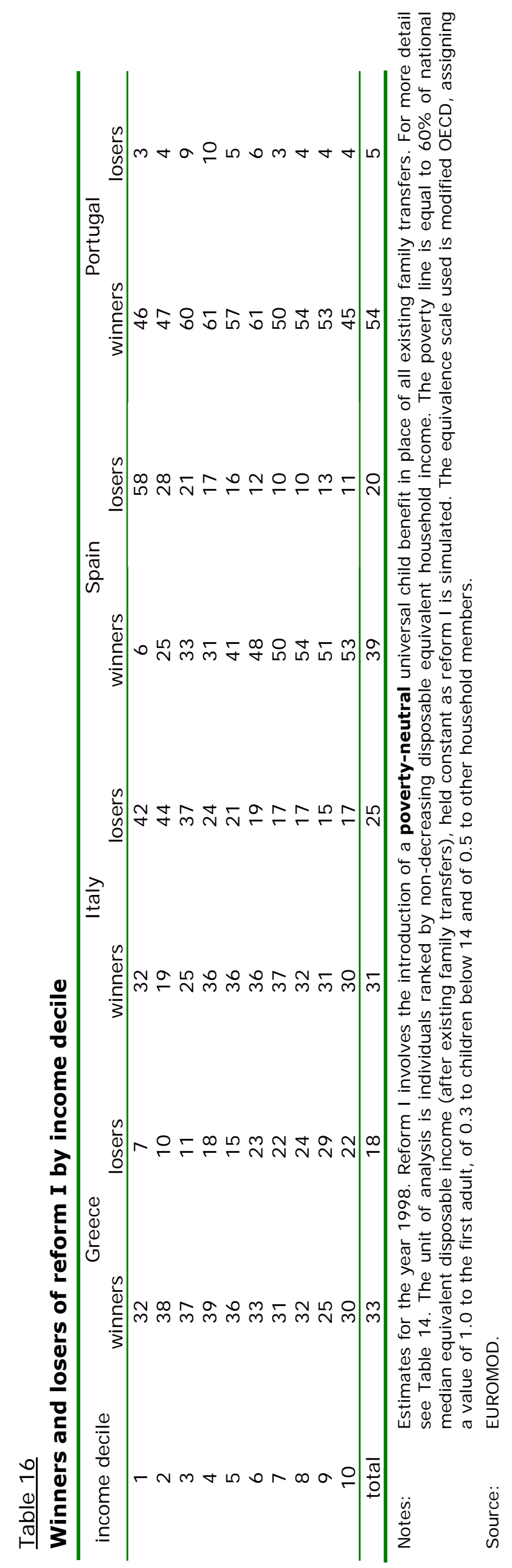




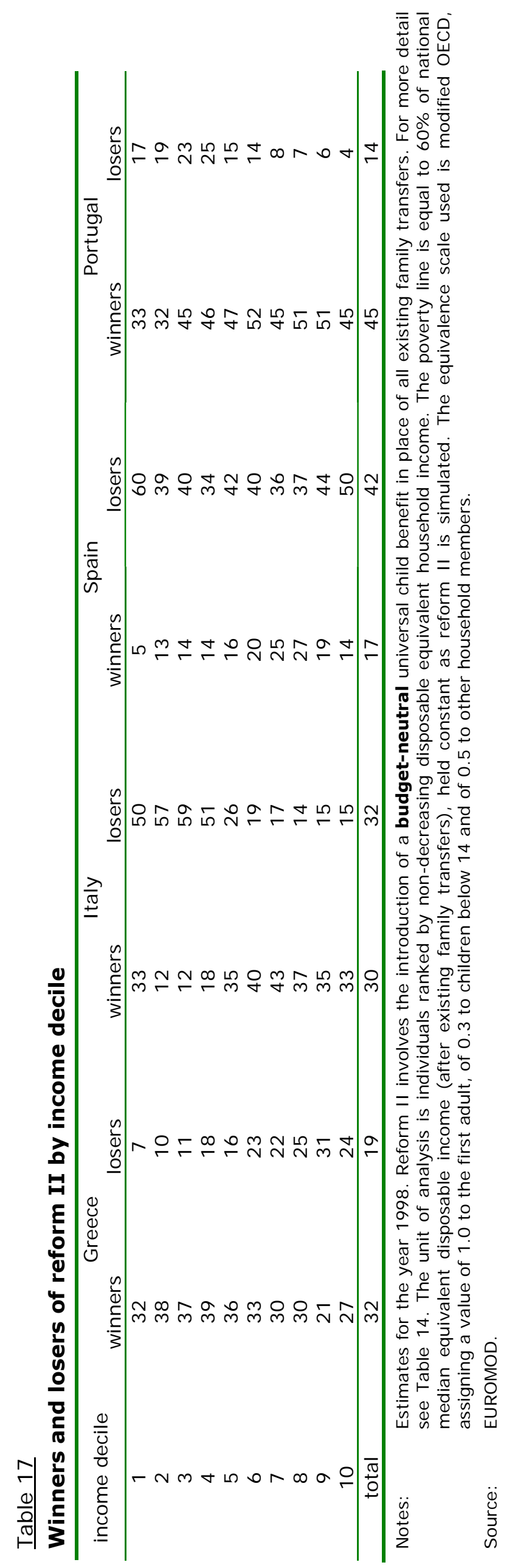




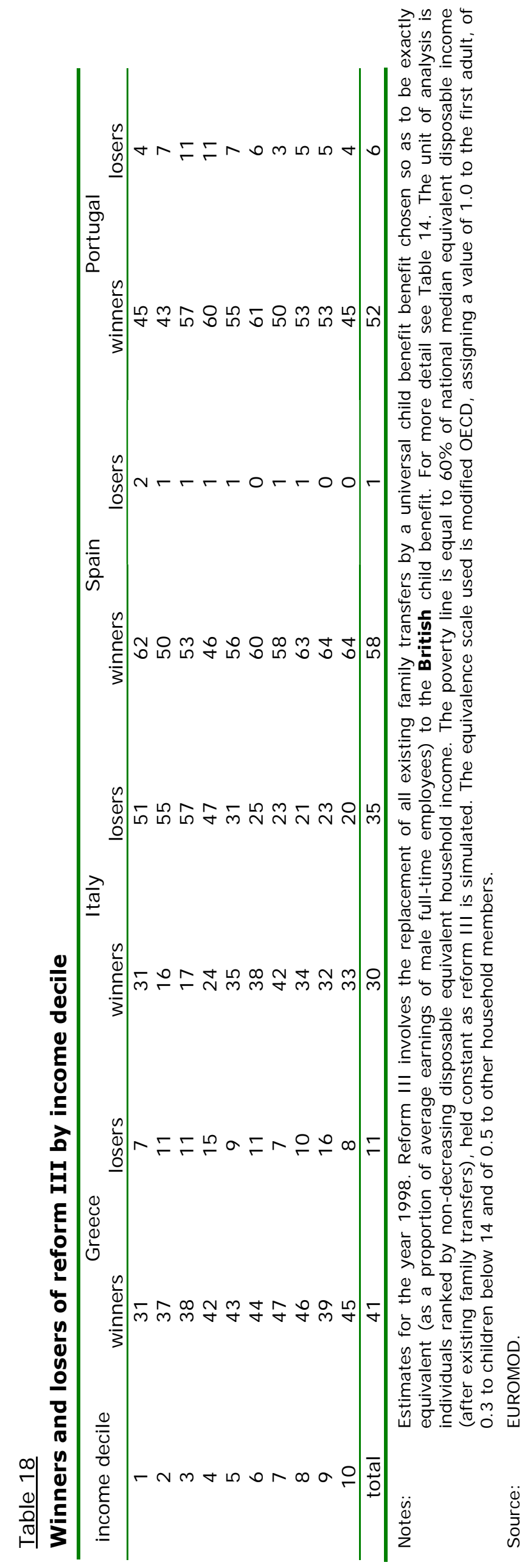




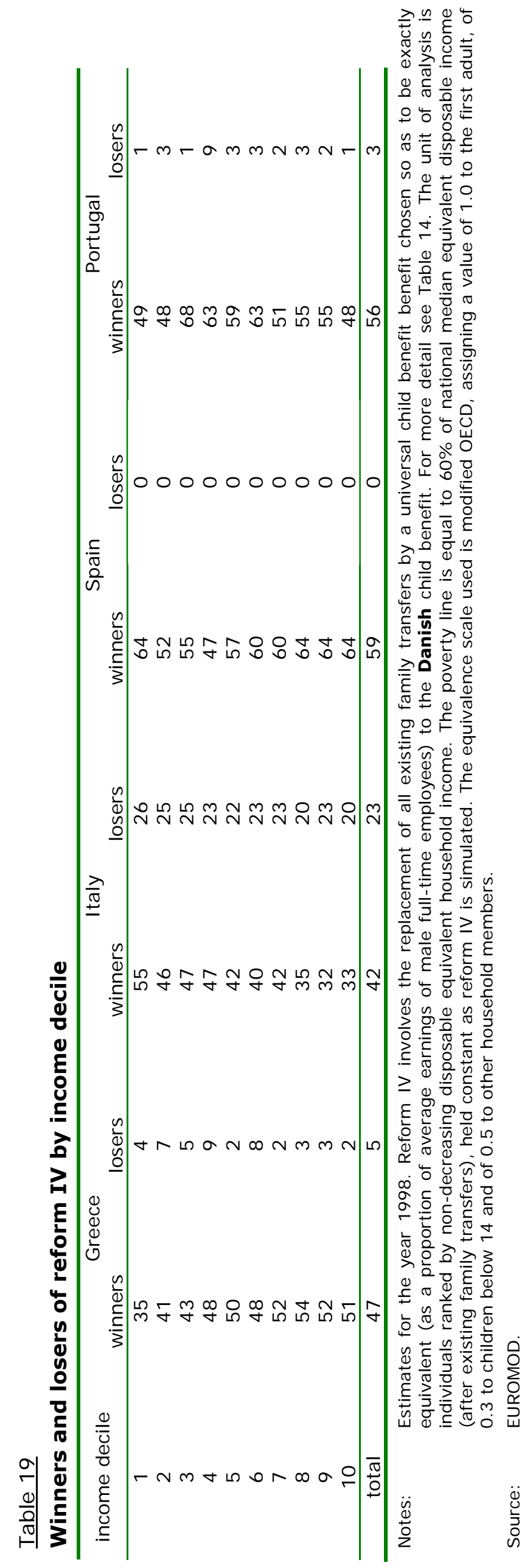




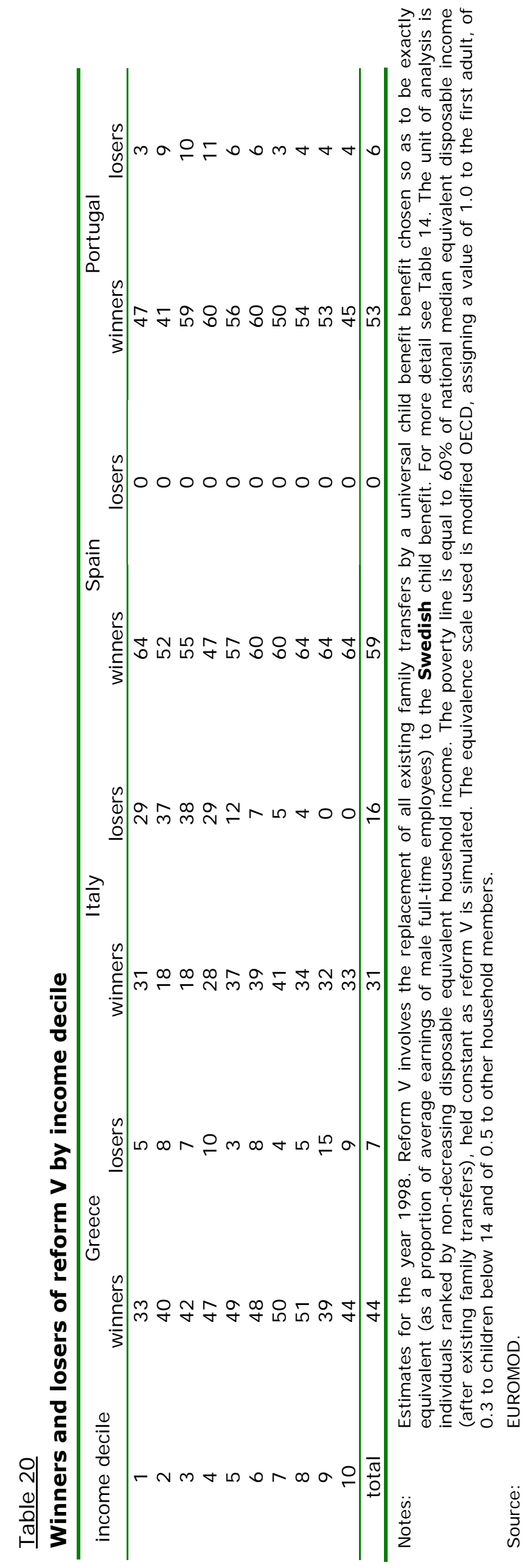




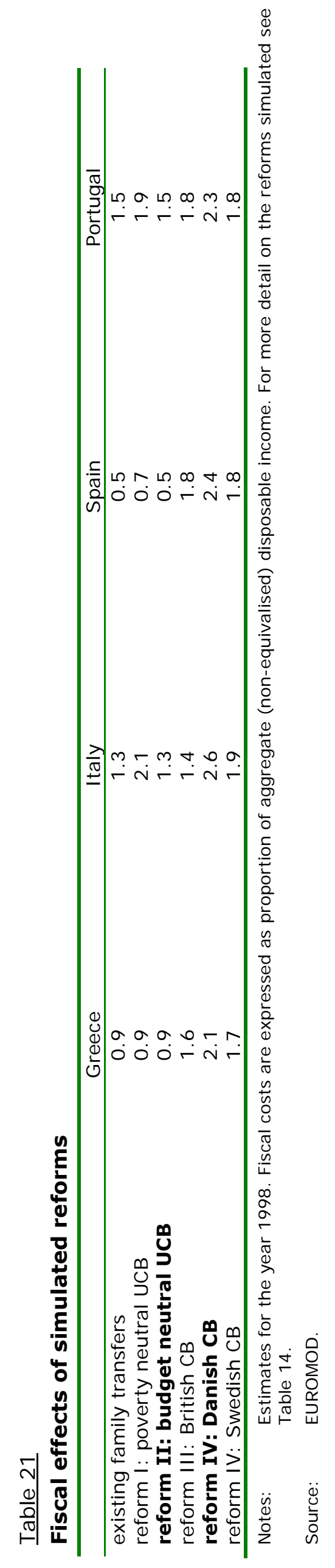



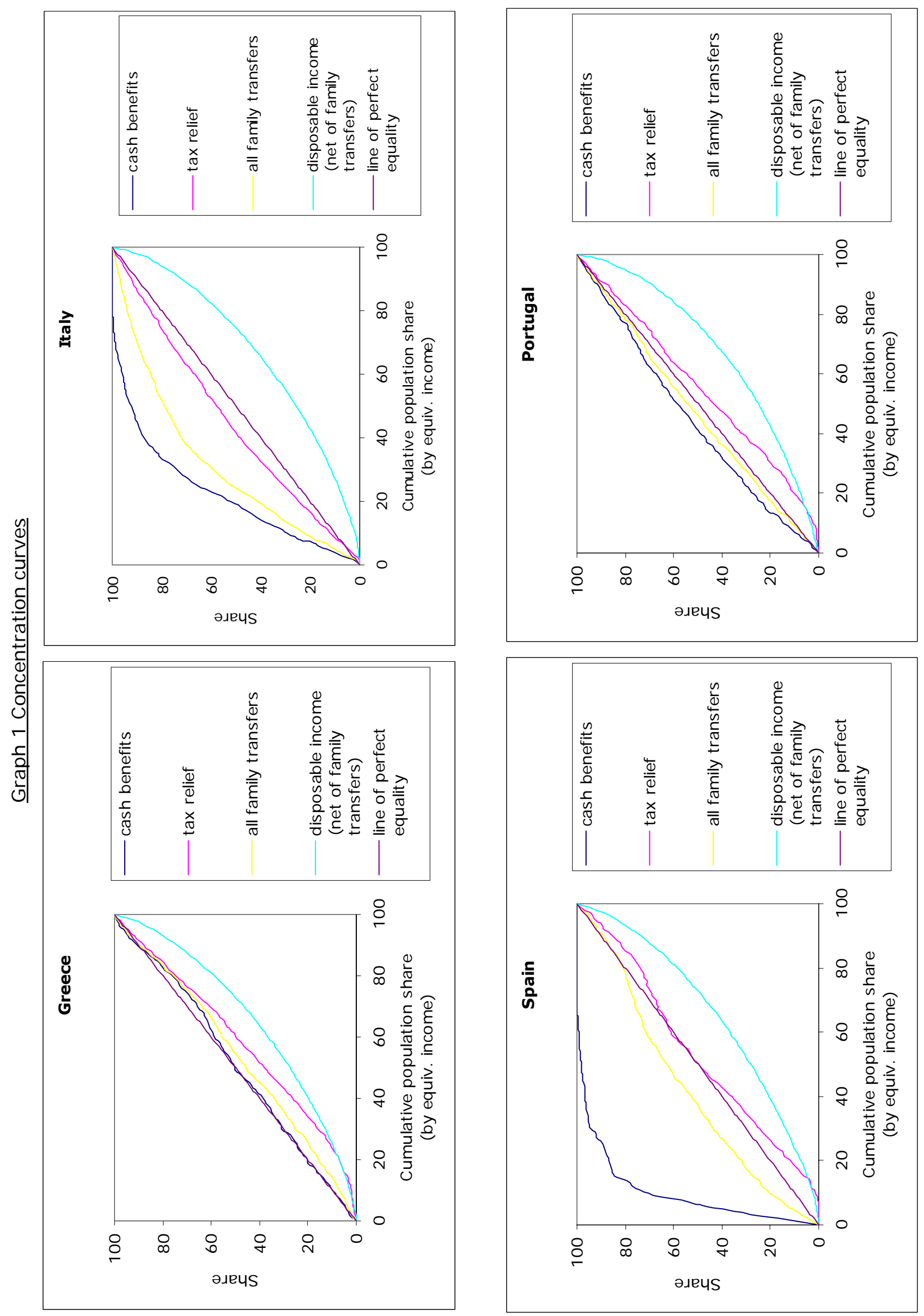


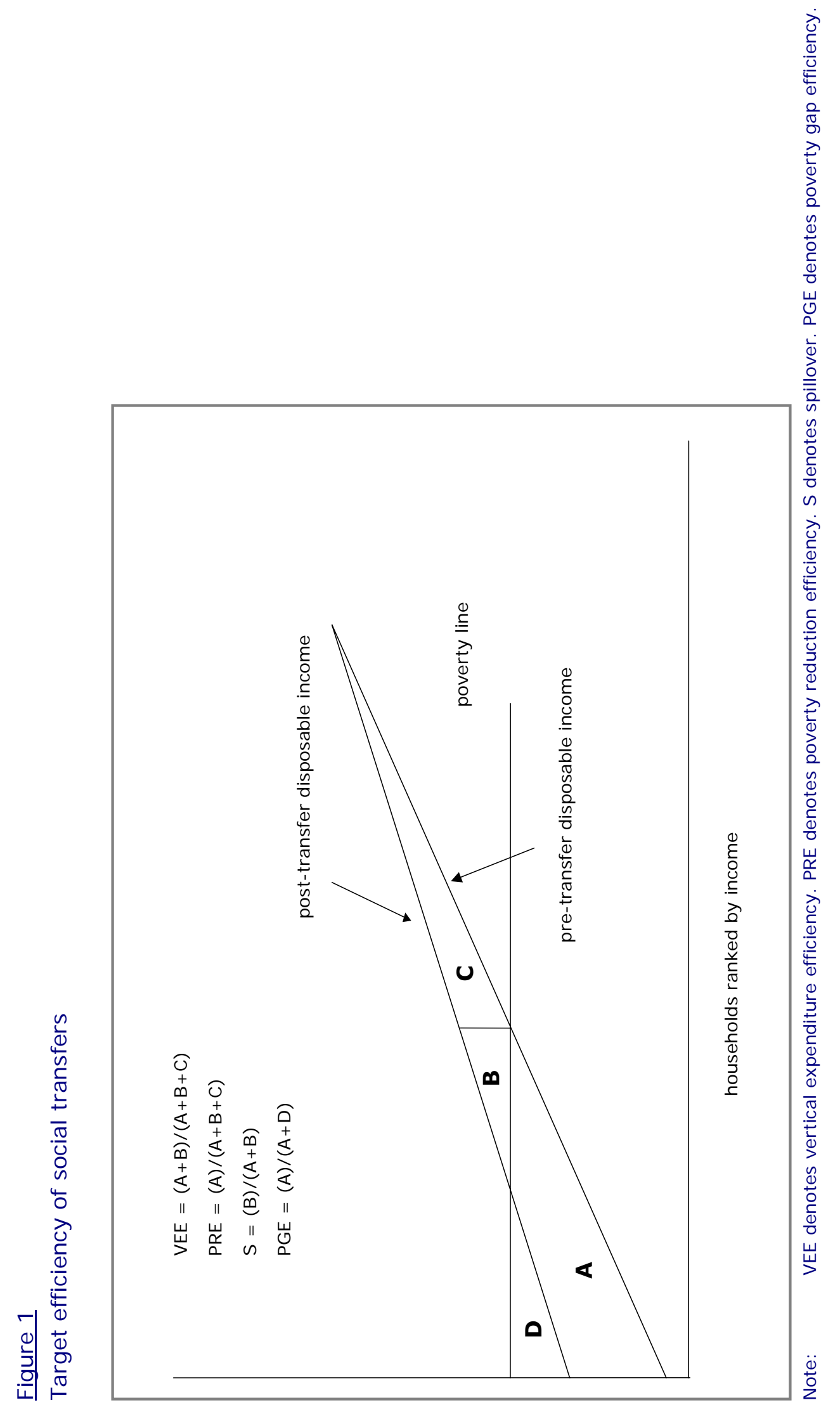




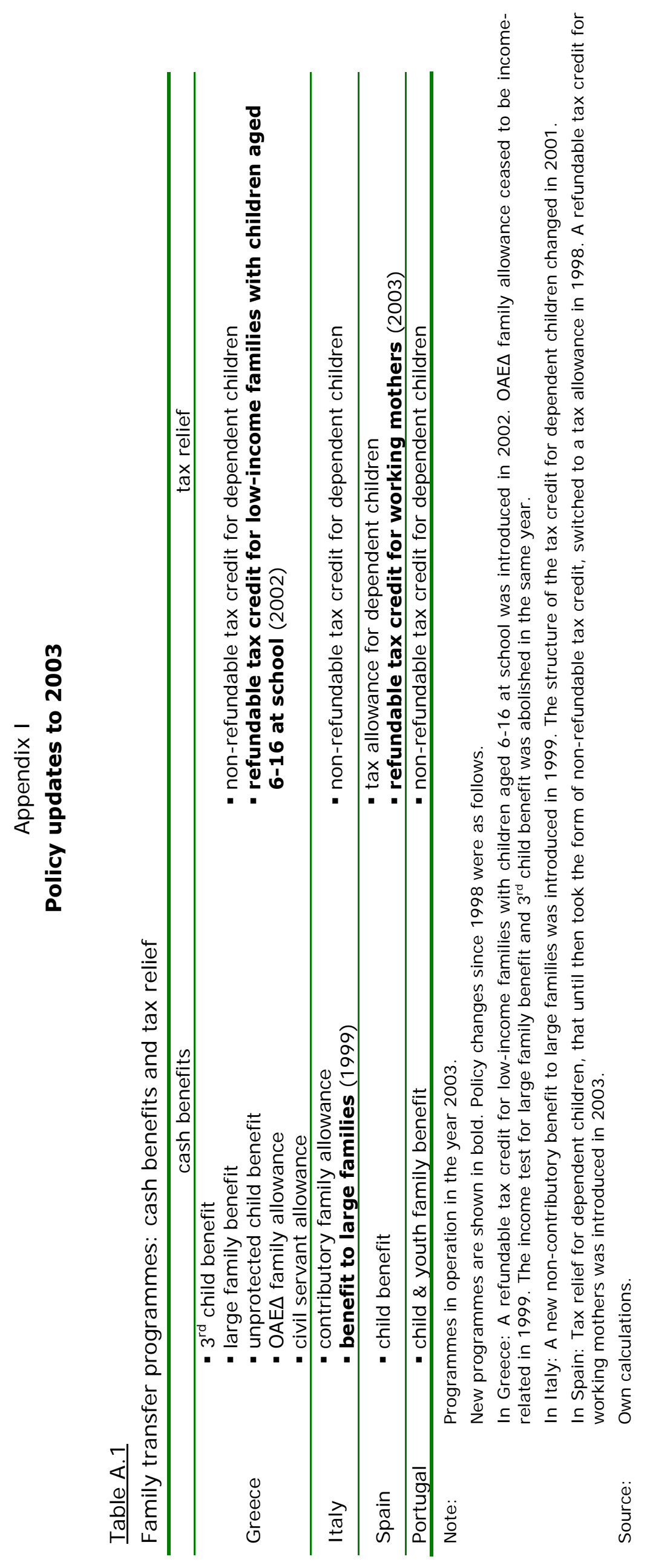




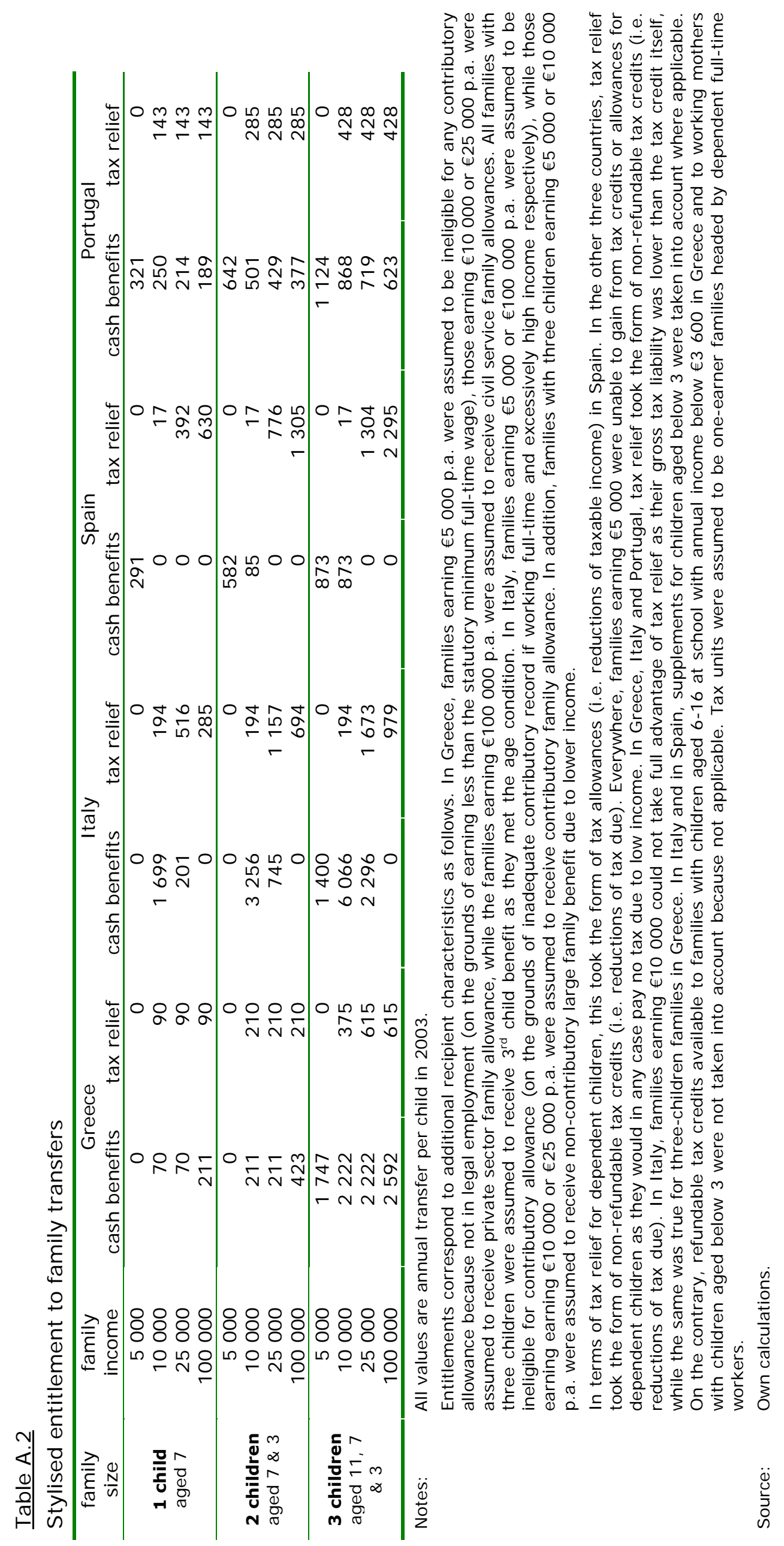




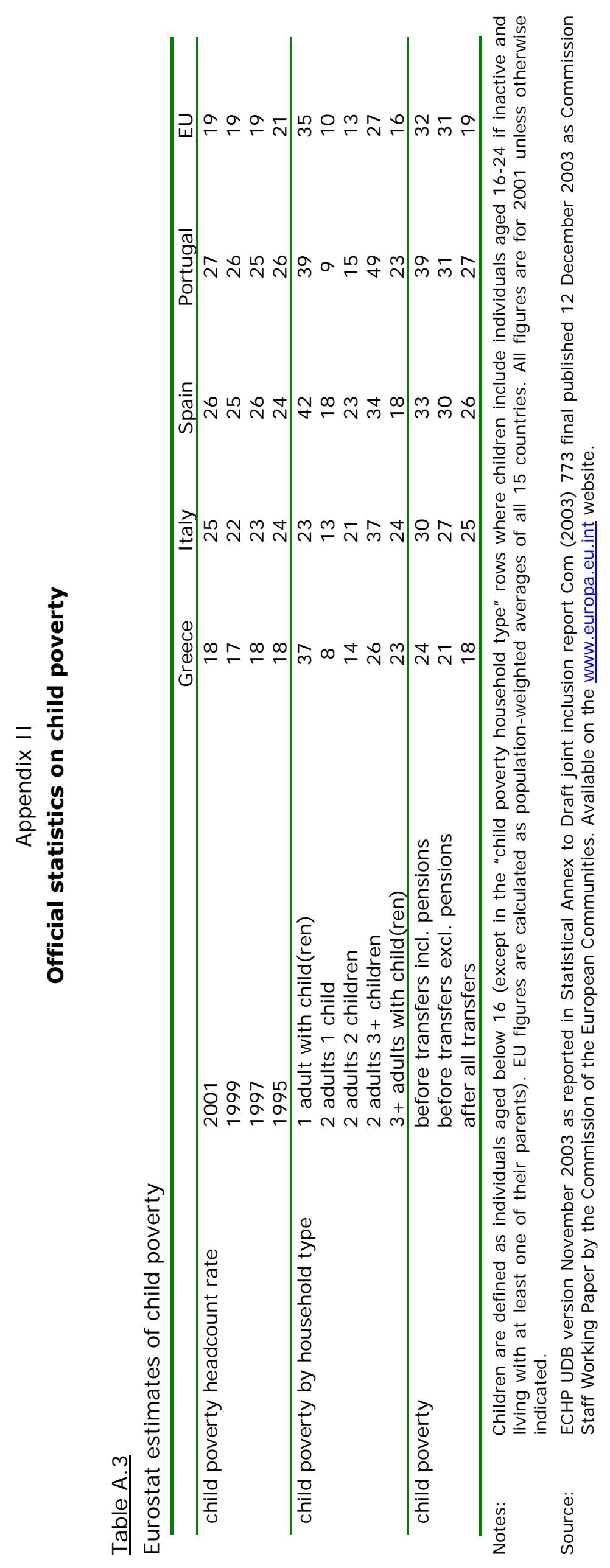

